\title{
Decision Analysis Science Modeling for Application and Fielding Selection Applied to Equipment Dismantlement Technologies
}

\author{
Final Report \\ January 1998
}

\author{
By: \\ M. A. Ebadian \\ L. E. Lagos
}

Work Performed Under Contract No.: DE-FG21-95EW55094

\author{
For \\ U.S. Department of Energy \\ Office of Fossil Energy \\ Federal Energy Technology Center \\ P.O. Box 880 \\ Morgantown, West Virginia 26507-0880 \\ By \\ Florida International University \\ Hemispheric Center for Environmental Technology (HCET) \\ Center for Engineering \& Applied Sciences \\ 10555 West Flagler Street \\ EAS-2100 \\ Miami, Florida 33174
}

RECEIVED

OCT 261998

OSTI 


\section{Disclaimer}

This report was prepared as an account of work sponsored by an agency of the United States Government. Neither the United States Government nor any agency thereof, nor any of their employees, makes any warranty, express or implied, or assumes any legal liability or responsibility for the accuracy, completeness, or usefulness of any information, apparatus, product, or process disclosed, or represents that its use would not infringe privately owed rights. Reference herein to any specific commercial product, process, or service by trade name, trademark, manufacturer, or otherwise does not necessarily constitute or imply its endorsement, recommendation, or favoring by the United States Government or any agency thereof. The views and opinions of authors expressed herein do not necessarily state or reflect those of the United States Government or any agency thereof. 


\section{DISCLAIMER}

Portions of this document may be illegible in electronic image products. Images are produced from the best available original document. 
During the decontamination and decommissioning (D\&D) activities being conducted by the U.S. Department of Energy (DOE), approximately 550,000 metric tons of contaminated metal will be generated by the disposition of contaminated buildings. The majority of the structural steel is considered to be radiologically contaminated. The D\&D activities require the treatment of the structural steel to reduce occupational and environmental radiological exposures during dismantlement. Treatment technologies may also be required for possible recycling.

Many proven commercial treatment technologies are available. These treatment processes vary in aggressiveness, safety requirements, secondary waste generation, necessary capital, and operation and maintenance costs. Choosing the appropriate technology to meet the decontamination objectives for structural steel is a difficult process. A single information source comparing innovative and nuclear and non-nuclear technologies in the areas of safety, cost, and effectiveness is not currently commercially available to perform a detailed analysis. This study presents comparable data related to operation and maintenance,- cost, and health and safety aspects of three readily available technologies and one innovative technology for nuclear decontamination. The technologies include: Advance Recyclable Media System (ARMS ${ }^{\text {ry }}$ ), NELCO Porta Shot Blast ${ }^{\text {tw }}$ (JHJ-2000), Pegasus Coating Removal System 7 (PCRS-7) and the innovative laser ablation technology called the Yag Eraser ${ }^{\mathrm{nt}}$. 


\section{TABLE OF CONTENTS}

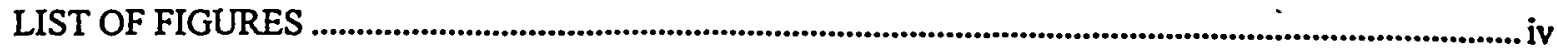

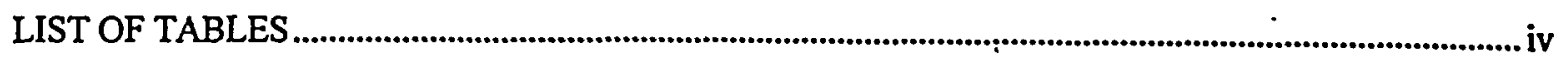

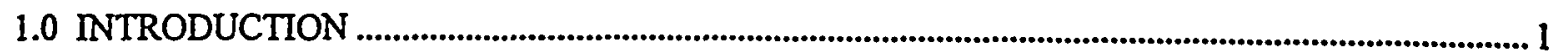

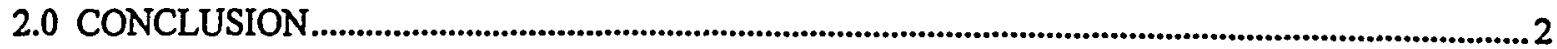

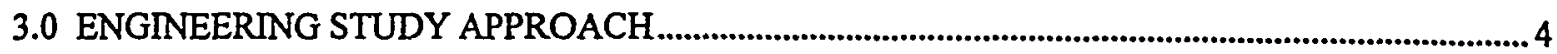

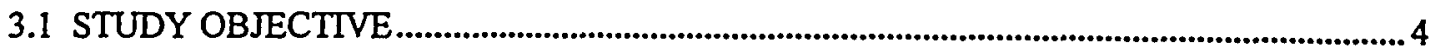

3.1.1 Determining the Types of Technologies to be Tested................................................ 4

3.1.2 Surrogate Selection and Preparation ........................................................................ 7

3.1.3 Comparing the End Point Achieved to the Decontamination

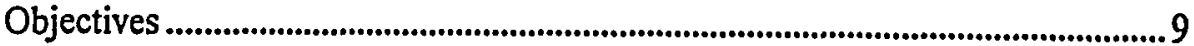

3.2 EXPERIMENTAL DESIGN AND PROCEDURES............................................................. 10

3.2.1 Methods of Obtaining Technology Vendors .................................................... 10

3.2.2 Test Location and Utilities Provided ................................................................. 10

3.2.3 Data Requirements ...................................................................................................11

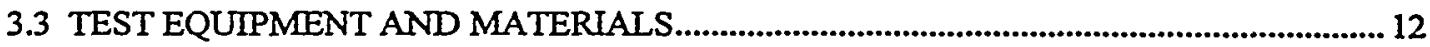

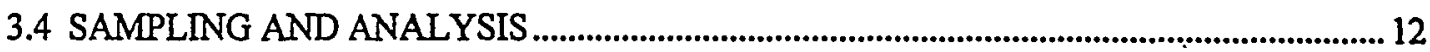

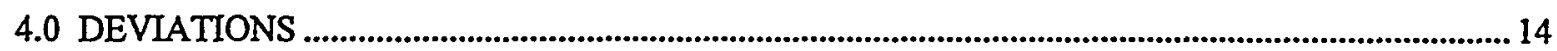

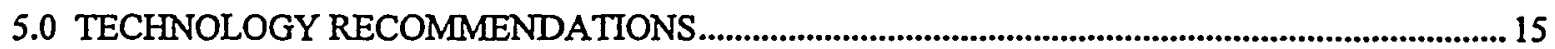

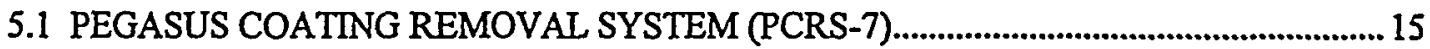

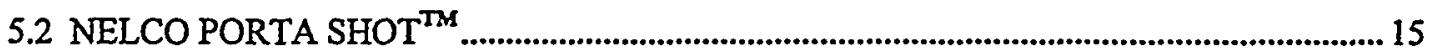

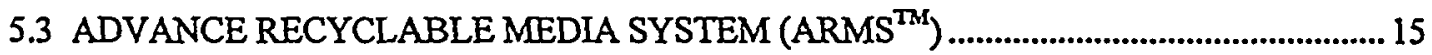

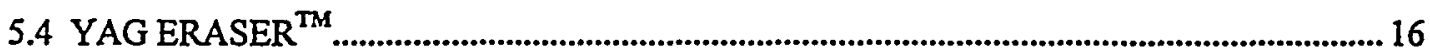

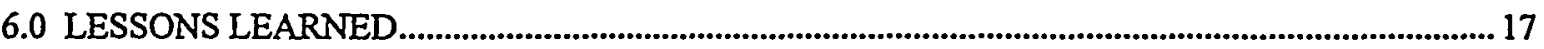

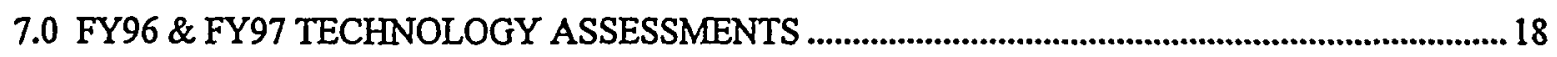

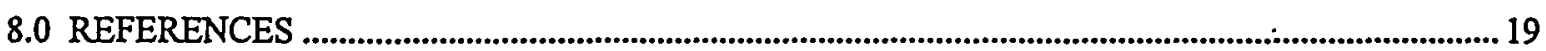

APPENDIX A. Job Safety Analysis

APPENDIX B. Technology Data Requirements: Definitions

APPENDIX C. Data Section

APPENDIX D. Vendor Information 
Figure 1. Surface removal production rate $\left(\mathrm{f}^{2} / \mathrm{hr}\right)$ for YAG ERASER ${ }^{\mathrm{Tw}}$, Advance Recyclable Media System (ARMS ${ }^{\text {T3 }}$ ), and NELCO Porta Shot Blast".

Figure 2. Surface removal production rate $\left(\mathrm{ft}^{2} / \mathrm{hr}\right)$ for Pegasus Chemical Coating Removal System (PCRS-7).

Figure 3. Application of PCRS-7 on a coated metal plate.

Figure 4. PCRS-7 removing coating from an I-beam.

Figure 5. NELCO Porta Shot Blast ${ }^{\text {Th }} \mathrm{JHJ}-2000$ removing coating from an I-beam.

Figure 6. NELCO Porta Shot Blast ${ }^{\mathrm{T}} \mathrm{JHJ}-2000$ removing coating from a metal plate.

Figure 7. $\mathrm{ARMS}^{\mathrm{N}}$ equipment with feed unit in foreground and sifter unit in background.

Figure 8. ARMS $^{\mathrm{TH}}$ operator removing coating from a metal plate......

Figure 9. YAG ERASER ${ }^{\mathrm{n}}$ removing coating from a metal plate.

Figure 10. YAG ERASER ${ }^{\text {nx }}$ removing rust from a metal plate.

Figure 11. Painted Plate.

Figure 12. Rusted Plate.

\section{LIST OF TABLES}

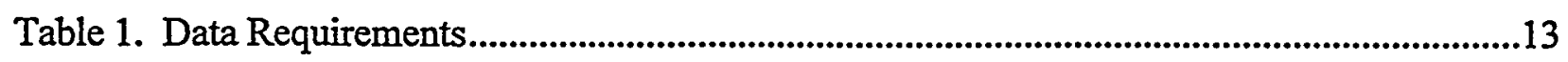

Table 2. Technologies for Metal Decontamination FY97 …........................................................18 


\subsection{INTRODUCTION}

In 700 previously identified buildings in the U.S. Department of Energy's (DOE's) current inventory, radioactive contamination levels and structural deterioration factors require the complete decommissioning of the facilities. Since an estimated 550,000 metric tons of scrap metal with varying degrees of contamination will be generated by the deconstruction process, technologies are currently being identified to reduce the volume of highly contaminated waste by mechanically separating the highly contaminated waste from the greater volume of low-level waste or uncontaminated material. The satisfaction of the driver criteria - cost, health and safety, etc.-will vary depending on the technology chosen. These driver criteria along with multidependent, site-variable objectives and decisions regarding the appropriateness of an individual technology or mix of technologies that may be applied to a remediation effort, require continuous review and reassessment. Defensible decisions are paramount in serving the multiple goals of the DOE's operating mandate.

To reduce risks to the environment and human health and to support the DOE's decontamination and decommissioning (D\&D) objectives, this project will evaluate and test innovative as well as nuclear and non-nuclear technologies for decontaminating the surface of radiologically contaminated metal. The evaluation will be conducted at the Hemispheric Center for Environmental Technology (HCET) at Florida International University (FIU) and will identify the most effective techniques for decontaminating DOE sites, providing a basis on which decisions about what technology would be most appropriate in the field can be made.

$D \& D$ activities require treating the structural steel to reduce occupational and environmental radiological exposures during dismantlement. Treatment technologies may also be required for possible recycling. Many proven commercial treatment technologies are available, and an extensive report on eight different blasting technologies was conducted by HCET in 1995. These treatment processes vary in aggressiveness, safety requirements, secondary waste generation, necessary capital, and operating and maintenance costs. Choosing the appropriate and most effective technology to meet the decontamination objectives for structural steel is a difficult process. A single information source comparing technologies in the areas of safety, cost, and effectiveness is not currently commercially available to perform a detailed analysis.

The two primary decontamination objectives are: (1) a reduction in the surface contamination levels to reduce potential personnel and environmental exposure and (2) the reduction of surface contamination levels to meet DOE Order 5400.5 for unrestricted use. Decontamination objectives are developed on a project- and/or site-specific basis. The decontamination of steel in the majority of the cases is surface cleaning, the removal of surface coating, and/or rust removal. The decontamination technology will be required to perform a surface cleaning, achieve a white metal surface, or reach some point between the two conditions. 
This study provides a source of comparable data for metal nuclear decontamination including innovative as well as nuclear and non-nuclear technologies. A summary of the data related to production rate achieved by the two commercially available technologies and one innovative technology are shown in Figure 1. The production rate shown is given for each of four metal surrogates used in this study. The information presented in this bar chart should be used in combination with the information provided in Appendix $\mathbf{C}$ to determine the technology that should be selected based on site-specific health and safety, operations, and waste management factors.

\section{Production Rate}

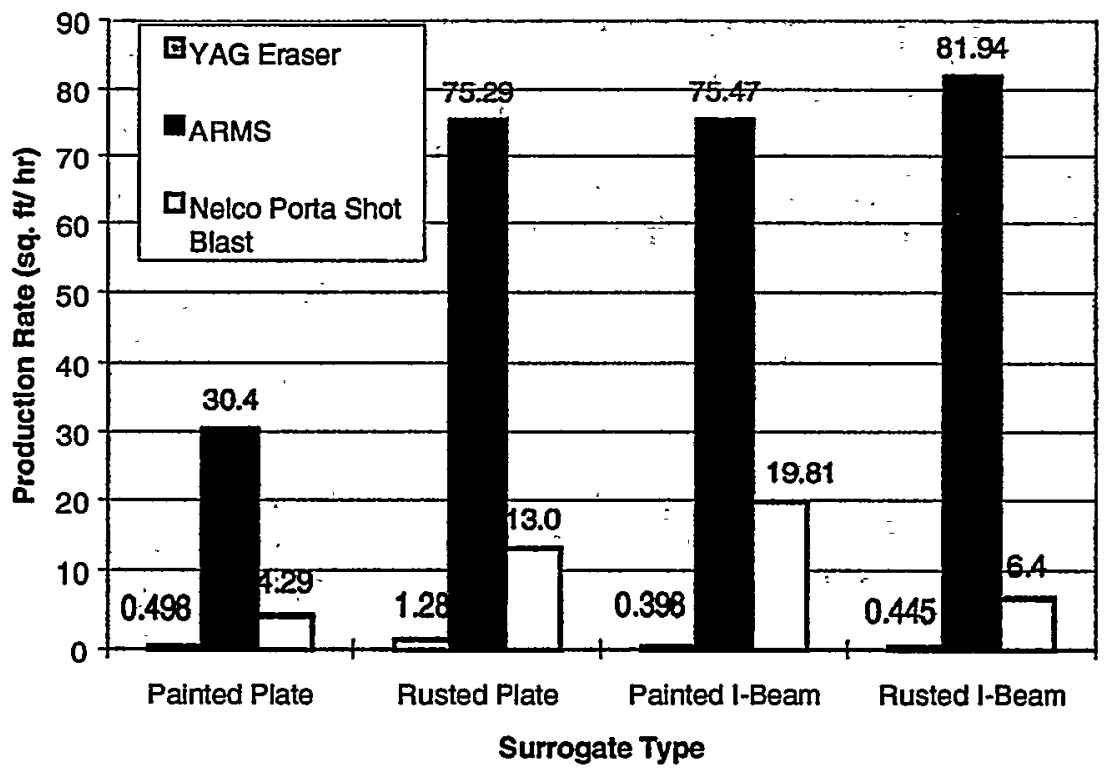

Figure 1. Surface removal production rate $\left(\mathrm{ft}^{2} / \mathrm{hr}\right)$ for $\mathrm{YAG}$ ERASER ${ }^{\mathrm{Tt}}$, Advance Recyclable Media System (ARMS ${ }^{\mathrm{Tu}}$ ), and NELCO Porta Shot Blast ${ }^{\text {2a }}$.

The production rate for the chemical removal technology, PCRS-7, is presented separately in Figure 2 because this technology did not conform to the test condition of four hours of consecutive operation. Instead, 10 painted plates and 10 painted I-beams were given to the vendor. The amount of time used for the application of the chemical and for its removal after it had set for approximately 24 hours was recorded. Figure 2 shows the production rate for PCRS-7 on two of the four metal surrogates. 


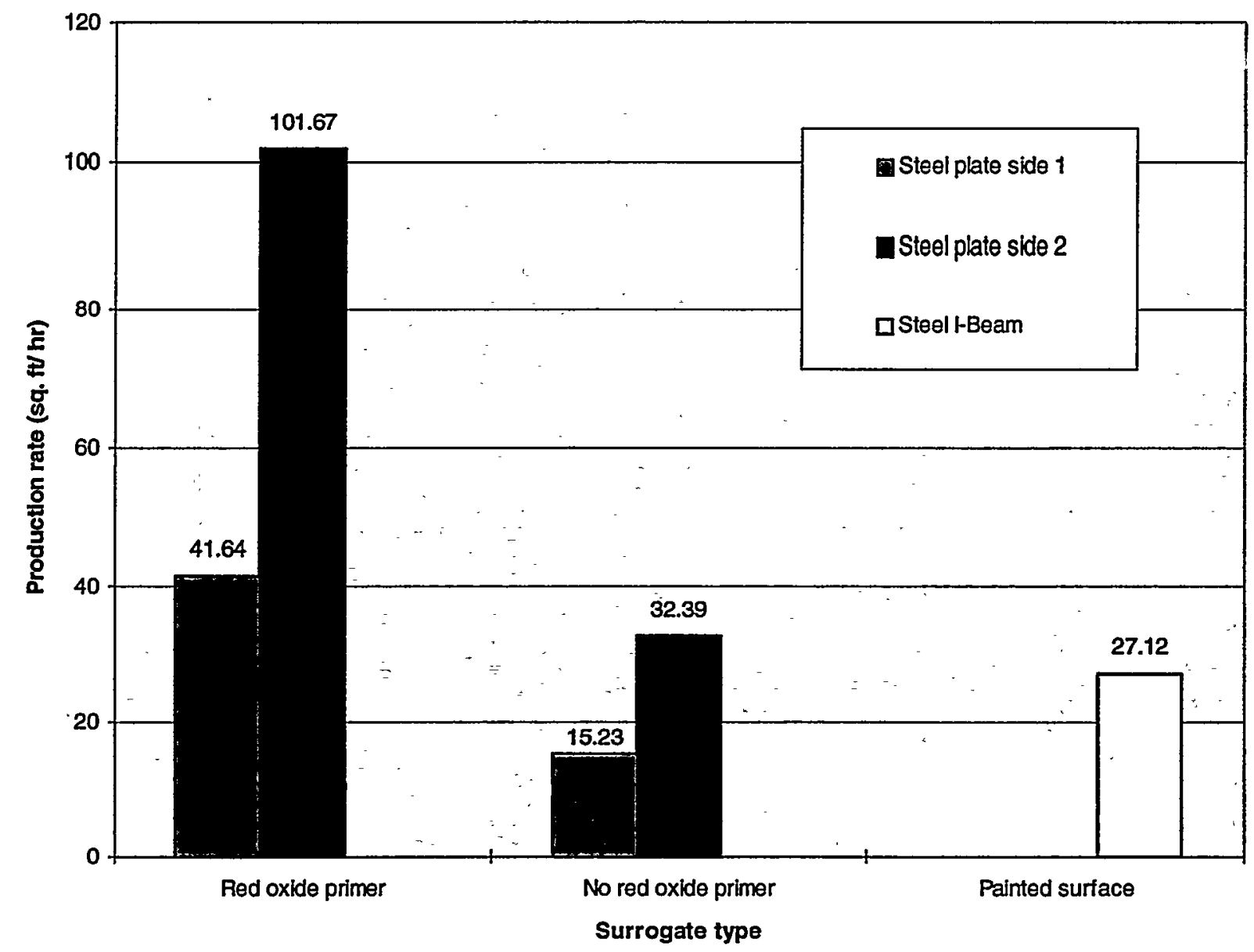

Figure 2. Surface removal production rate $\left(\mathrm{ft}^{2} / \mathrm{hr}\right)$ for Pegasus Chemical Coating Removal System (PCRS-7).

We conclude from this investigation that the four technologies reviewed demonstrated both positive and negative operational characteristics that must be considered before the technologies can be implemented at a specific site. The field engineer should be aware of the benefits and limitations posed by each technology. The proper solutions to meet decontamination objectives are site specific. The data presented in Appendix $\mathrm{C}$ comprise the deliverables of this study and are intended to represent the factors that are required to make these site-specific decisions.

Within each technology class, a group of sub-categories has been reviewed. These individual subcategories offer technology alternatives that may improve the technology's overall viability in achieving individual decontamination objectives. These technological differences, which are beyond the scope of this study, may be the subject of future investigation. 


\subsection{ENGINEERING STUDY APPROACH}

\subsection{STUDY OBJECTIVE}

The objective of this study was to perform a comparative analysis of innovative and nuclear and non-nuclear metal decontamination technologies applicable to the D\&D of DOE structures. The basis for this comparative analysis included the following:

- Determining the types of technologies to be tested

- Selecting and preparing surrogates

- Comparing the end point achieved to the DOE decontamination objectives

\subsubsection{Determining the Types of Technologies to be Tested}

Established sources and databases were used for categorizing and performing the initial screening of technology types. These sources and databases included:

- DOE/EM-0142P Decommissioning Handbook

- ORNL/M-2751 Oak Ridge National Laboratory Technology Logic Diagram

- EGG-WTD-11104 Idaho National Engineering Laboratory Decontamination and Decommissioning Technology Logic Diagram

- Fernald Environmental Restoration Management Corporation (FERMCO), 1994, Operable Unit 3 Treatability Study Work Plan, FERMCO, Cincinnati

- Remedial Action Program Information Center (RAPIC) database.

These sources provided a screening based on the applicability of a technology to a given material and contaminant. Considering this review, the following innovative and nuclear and non-nuclear technologies were tested during fiscal year 1997 (FY 97):

- Pegasus Chemical Coating Removal System (PCRS-7)

- NELCO Porta Shot Blast ${ }^{\text {Tx }}$ (JHJ-2000)

- Advance Recyclable Media System (ARMS ${ }^{\mathrm{NH}}$ )

- Laser Ablation (YAG ERASER ${ }^{\text {TxM }}$ )

\subsubsection{Pegasus Chemical Coating Removal System}

PCRS-7 is a chemical coating removal method that has been developed by Pegasus International, Inc. for the removal of chemically resistant coatings (i.e., epoxies, urethanes, chlorinated coatings, rubber, elastomeric coatings, aluminum, vinyls, mastics, and most marine coatings). The PCRS-7 is an organic solvent mixture. It is light beige in color, slightly sweet in odor, and is 
supplied in 1-, 5-, or 55-gallon plastic buckets. Depending on the substrate and operating conditions, PCRS-7 is applied by pouring it directly from the bucket or from a smaller container, and using long- or short-handled spreaders or trowels to distribute it evenly across the surface. It can also be applied using a sprayer. Once distributed, the chemical is covered by a single layer of white freezer paper. Removal of the PCRS-7 and primary waste is achieved by lifting and removing the paper followed by scraping the surface using trowels or large plastic shovels. Figure 3 shows the application of PCRS-7 with a trowel. Figure 4 shows the PCRS-7 removing coating from an I-beam.

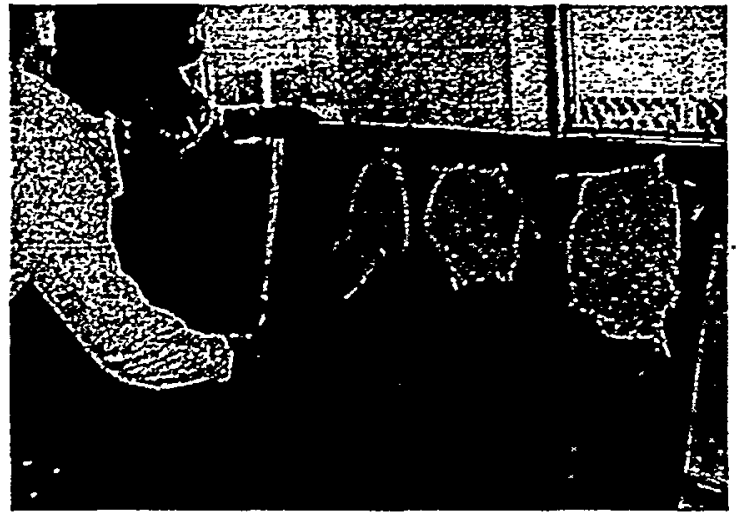

Figure 3. Application of PCRS-7 on a coated metal plate.

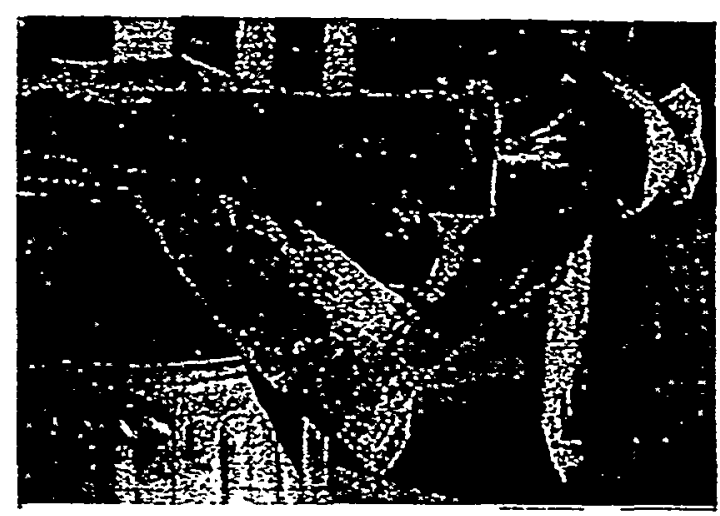

Figure 4. PCRS-7 removing coating from an I-beam.

\subsubsection{NELCO Porta Shot Blast ${ }^{\text {TW }}$ JHJ-2000}

The NELCO Porta Shot Blast ${ }^{\mathrm{T}}$ JHJ-2000 is a hand-held portable steel shot blaster. This unit has a 1 inch $\times 1.7$ inch blast pattern and a $1 / 2-\mathrm{HP}$ electric/pneumatic motor. The debris accumulate in the dust collector, and the shot accumulates in the hopper after rebounding from the work surface. Gravity then pulls the shot into the impeller where it is recycled. The blaster holds approximately 2 pounds of shot. Horizontal, vertical, and overhead hoppers are included for various working conditions. This unit is also equipped with a dual safety shut-off valve. Figures 5 and 6 show the $\mathrm{JHJ}-2000$ removing coating from an I-beam and a metal plate. 


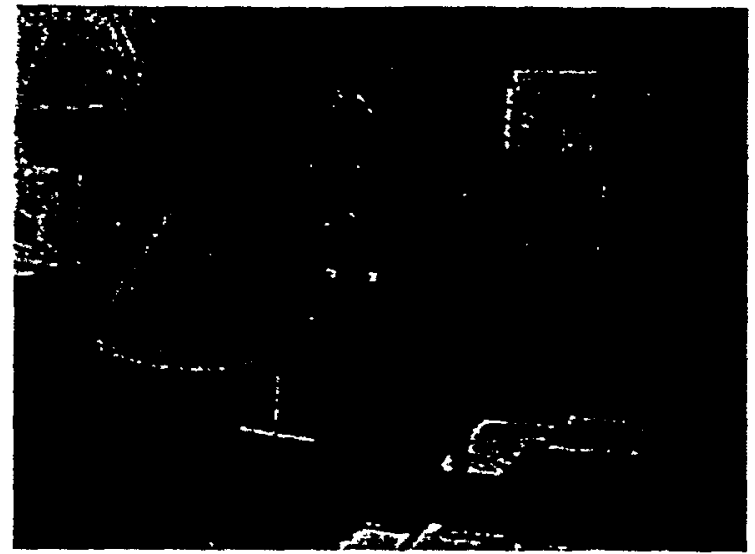

Figure 5. NELCO Porta Shot Blast JHJ2000 removing coating from an l-beam.

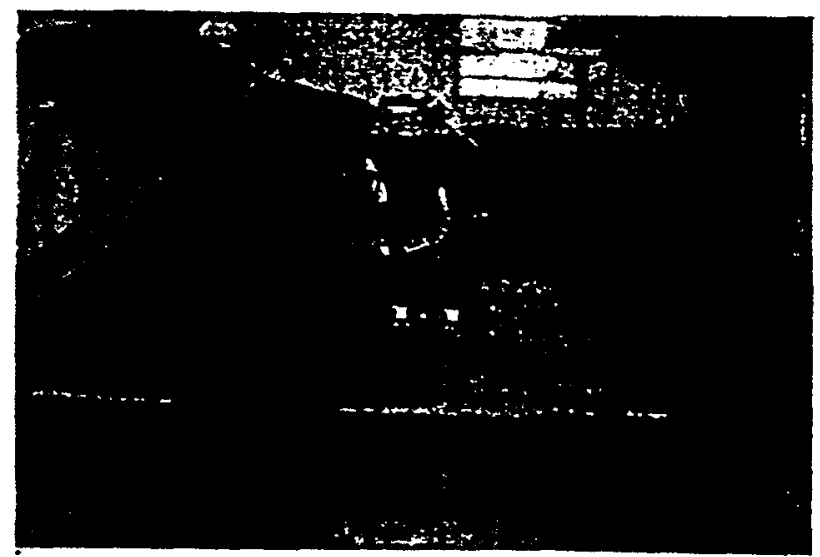

Figure 6. NELCO Porta Shot Blast ${ }^{\mathrm{Tu}}$ JHJ-2000 removing coating from a metal plate.

\subsubsection{Advance Recyclable Media System}

The ARMS ${ }^{\text {tw }}$ uses a man-made media to remove coatings and rust from surfaces. The removal process is achieved by using an open blast method where the media is propelled to the surface by using compressed air. The ARMS equipment consists of the feed unit and the sifter unit. The feed unit is a portable, pneumatically powered device that propels the cleaning media against the surfaces to be decontaminated. The cleaning media is contained in the hopper mounted atop the unit. The media is fed to an auger device that mixes the cleaning media with compressed air. The sifter unit is a machine that mechanically removes large debris and powdery residues from the cleaning media after use. The unit vibrates causing the media to fall downward to a series of separation screens that separate the debris from the media. The reusable media drastically reduces the waste generated per square foot of surface treated. Figures 7 and 8 show the ARMS ${ }^{\text {Th }}$ equipment and operator removing coating from a metal plate.

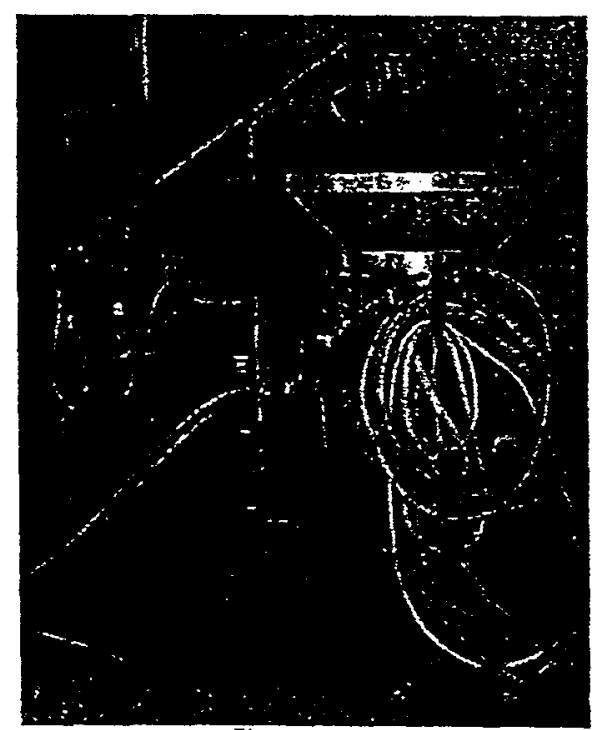

Figure 7. ARMS ${ }^{\text {nd }}$ equipment with feed unit in foreground and sifter unit in background.

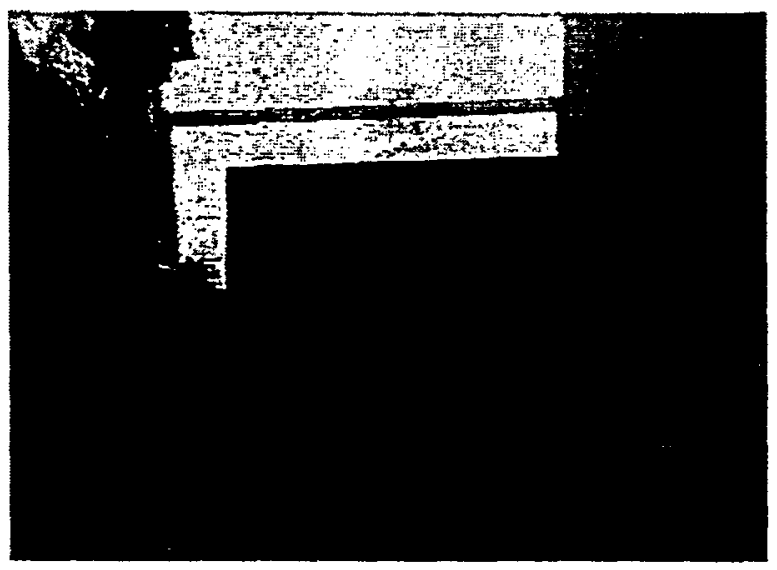

Figure 8. ARMS ${ }^{\text {in }}$ operator removing coating from a metal plate. 


\subsection{1.t Y.AG ERASER ${ }^{*}$}

The YAG ERASER ${ }^{\text {n }}$ technology system consists of a laser light that ablates coatings from various surfaces. The intensity and shape of the light is designed to control and minimize the damage of the substrate being decontaminated. A specialized optical fiber helps transmit the laser light to a hand-held work head. The work head consists of control and feedback systems. The control system allows the operators to adjust the stripping rate and area of the path of removal, to start and stop the stripping process, and to provide an emergency stop function. The feedback systems provide the operator with a visual representation of the surface that is being removed and the input to the laser control software. The work head also consists of a vacuum line that collects any gases or particles that are present at the surface. The vacuum line is connected to a waste management system consisting of HEPA filters and charcoal pellets. Figures 9 and 10 show the YAG ERASER ${ }^{\text {tw }}$ removing coating from a coated metal plate and removing rust from a rusted plate.

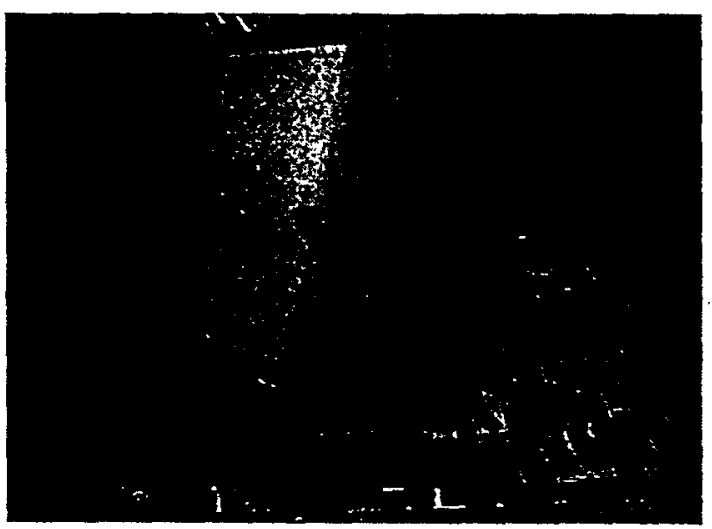

Figure 9. YAG ERASER ${ }^{\text {nu }}$ removing coating from a metal plate.

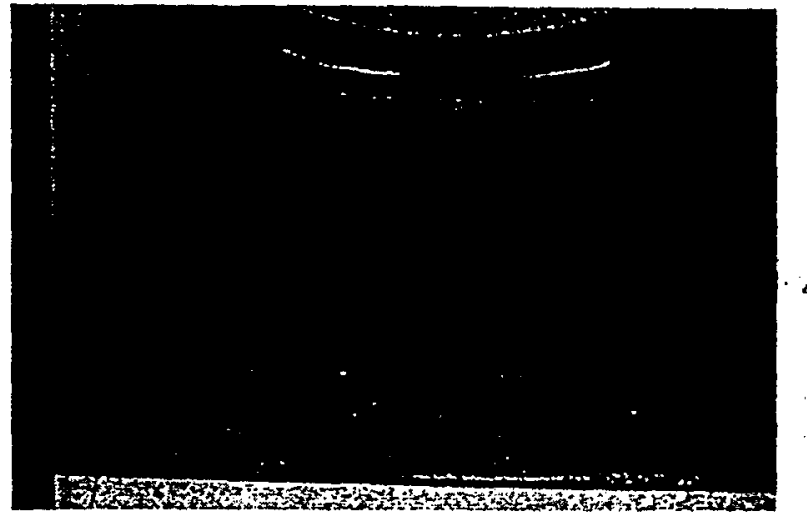

Figure 10. YAG ERASER ${ }^{\mathrm{n}}$ removing rust from a metal plate.

\subsubsection{Surrogate Selection and Preparation}

The decontamination of steel, in most cases, consists of surface cleaning or removing coatings and/or rust. The amount of steel that will require the removal of base metal is negligible at most DOE sites. These assumptions allow the use of surrogate materials to simulate the largest structural steel decontamination problems at any DOE site. The surrogates consisted of W6 69 I-beams cut to be approximately 10 feet in length, and steel plates of a minimum $1 / 4$-inch thickness cut to be approximately 4 feet $\times 4$ feet square. The I-beams were prepared and coated using a standard industrial coating. I-beams that exhibited a rusted condition, like the ones found at many DOE sites, were also prepared/collected. The steel plates were prepared and painted with a coating typically used in chemically exposed environments. Steel plates that exhibited a rusted condition, like ones found at many DOE sites, were also prepared/collected. A local vendor was procured to prepare and paint the I-beams and plates to meet the required specifications. The 
remaining I-beams and plates were procured through a scrap dealer or a structural steel manufacturer/distributor. The option of procuring steel and allowing it to oxidize until it acquired the desired "rusted" condition was also used.

The following paint specifications were used to develop the painted surrogates:

- I-beam Specification. (1) Prepare metal according to the Michael A. Bruder \& Son (M.A.B.) technical data and application instructions. (2) Apply Rust-O-Lastic Anti-Corrosive Primer 3 mils wet to obtain 1 1/2-mils dry film thickness. (3) Wait 24 hours, then apply a finish coat of Rust-O-Lastic finish coating at 3 mils wet to obtain $1 \frac{1}{2}$-mils dry film thickness.

- Plate Specification. (1) Prepare metal according to the M.A.B. technical data and application instructions. (2) Apply Ply-Mastic at 8 mils wet to obtain a 7-mils dry film thickness. (3) Wait 24 hours, then apply finish coat of Ply-Thane 890 coating at 3 mils wet to obtain $1 \frac{1}{2}$-mils dry film thickness.

The following figures represent the four surrogates used in this study. A painted plate is shown in Figure 11, a rusted plate is shown in Figure 12, a painted I-beam is shown in Figure 13, and a rusted I-beam is shown in Figure 14.

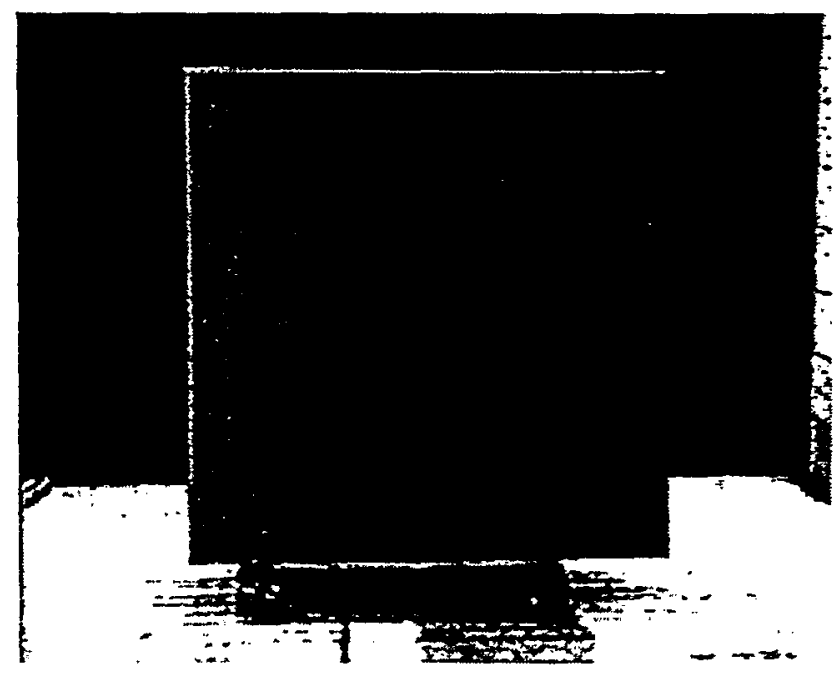

Figure 11. Painted Plate.

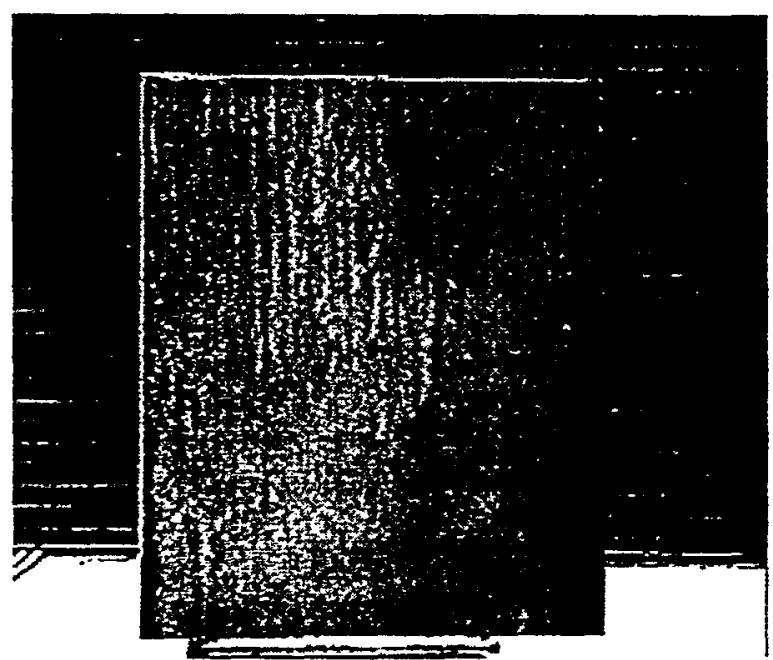

Figure 12. Rusted Plate. 


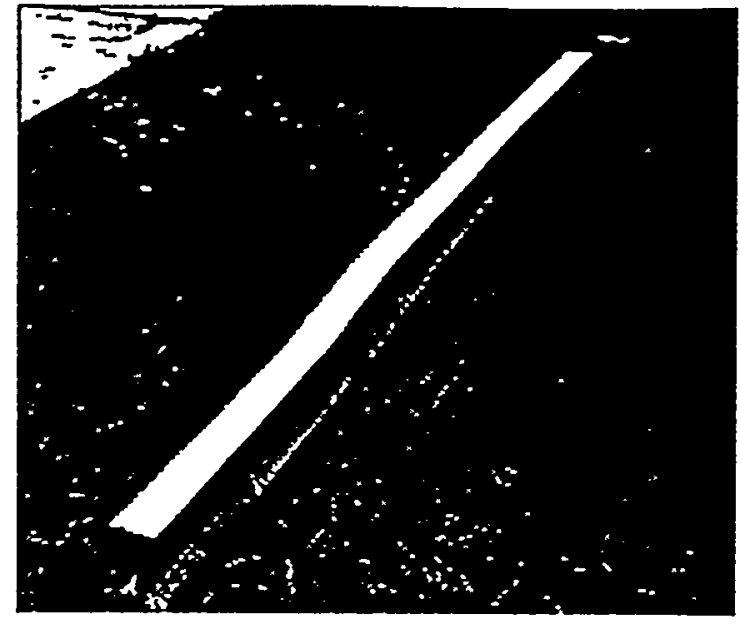

Figure 13. Painted l-beam.

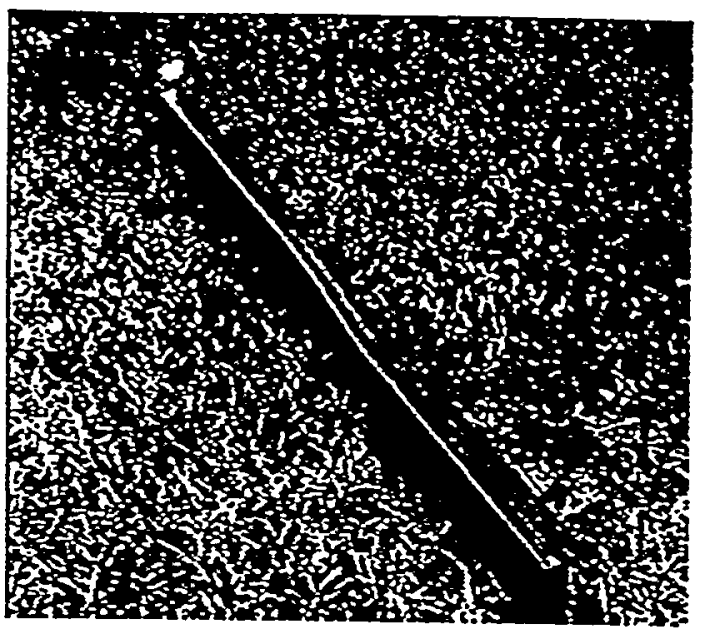

Figure 14. Rusted l-beam.

\subsubsection{Comparing the End Point Achieved to the Decontamination Objectives}

To ensure the results of this test were applicable to the different decontamination objectives and to other environmental restoration sites, the technologies were used in the most efficient manner as dictated by the vendor. The end point achieved was compared to a set of established surface finish standards. A surface end point definition for different surface conditions was then given based on the review of the specifications of the Steel Structures Painting Council, USA, and the National Association of Corrosion Engineers, USA. These specifications do not apply to the removal of radiological contamination. These specifications are as follows:

- Solvent-Cleaned Surface. The solvent cleaned surface shall be free of all visible oil, grease, dirt, dust, drawing and cutting compounds, and other detrimental contaminants from the steel surface. The solvent cleaned surfaces may still have rust, rust scale, or mill scale.

- Brush-Off Cleaned Surface. The brush-off cleaned surface shall be free of all visible oil, grease, dirt, dust, base mill scale, loose rust, and loose paint (i.e., tightly adhered particles that cannot be removed by lifting with a dull putty knife).

- Commercially Cleaned Surface. A commercially cleaned surface, when viewed without magnification, shall be free of all visible oil, grease, dirt, dust, mill scale, rust, paint and oxides, corrosion products, and other foreign matter, except for staining. Staining shall be limited to no more than 33 percent of each square inch of the surface area and may consist of light shadows, slight streaks, or minor discolorations caused by rust stains, mill scale stains, or previously applied paint stains. Slight residues of rust and paint may also be left in the bottom of pits if the original surface is pitted.

- Cleaned Near-White Metal Surface. A cleaned near-white surface, when viewed without magnifications, shall be free of all visible oil, grease, dirt, dust, mill scale, rust, paint and oxides, corrosion products and other foreign matter, except for staining. Staining shall be limited to no more than five percent of each square inch of the surface area and may consist of 
light shadows, slight streaks or minor discolorations caused by rust stains, mill scale stains, or previously applied paint stains.

- Cleaned White Metal Surface. A cleaned white surface, when viewed without magnification, shall be free of all visible oil, grease, dirt, dust, mill scale, rust, paint and oxides, corrosion products, and other foreign matter. The surface should have a slightly roughened gray white, uniform metallic color.

\subsection{EXPERIMENTAL DESIGN AND PROCEDURES}

Each technology was tested for a minimum of four hours of actual operating time for each surrogate, providing sufficient time to collect the operational and safety information required for each technology. Additional data were collected on the capital costs, maintenance costs, and equipment staging/breakdown costs. The experimental design consisted of the following factors:

- Methods of obtaining technology vendors.

- Test location and utility parameters

- Data requirements

\subsubsection{Methods of Obtaining Technology Vendors}

The request for qualifications of prospective bidders was advertised in the Commerce Business Daily $(C B D)$. The advertisement identified the type of work to be contracted and the minimum qualifications for bidders. Qualified and interested bidders were asked to submit an expression of interest. The purpose of the advertisement was to pre-qualify prospective bidders to determine if they would indeed meet the qualification standards. The qualifications for the bidders included the number of years of work experience in nuclear decontamination and references of previous work performed using the proposed technology.

Following the bid closing date, the bids were reviewed to ensure that the lowest bidder was responsive and responsible. Determination of responsiveness was based on properly completing bid forms and acknowledging any amendments to the invitation for bid. The lowest bidder was deemed responsible if this bidder possessed the capability and experience as required in the solicitation to perform the test in a safe and timely manner.

\subsubsection{Test Location and Utilities Provided}

The tests were performed under the supervision of HCET personnel at the campus of FIU. The area available for testing consisted of an enclosure 10 feet wide $\times 16$ feet long $\times 10$ feet high. The enclosure was equipped with a ventilation system maintaining 0.1 inch of water negative pressure at 10 air exchanges per hour. The enclosure was capable of collecting any generated secondary waste.

The following utilities were available for use by the technology vendors:

- 60-psi, 6-gpm portable water supply 
- 110-volt, 15-amp single phase power supply

\subsubsection{Data Requirements}

General Information

- Technology description

- Equipment requirements

\section{Cost Information}

- Capital cost for the purchase of equipment

- Utility cost

- Maintenance cost

- Unit/operating cost

Operational Data

- Production rates

- End point achieved

- Labor classification

- Limitations

- Utility requirements

* Power consumption calculations

* Utilities required to operate the technology

- Environmental conditions

- Secondary waste management .

* Physical condition of secondary waste

* Quantity of media used

* Volume of secondary waste

* Characteristics of media

* Weight of secondary waste

- Equipment portability

- Measurement of fuel used

- Operation and maintenance requirements

Implementation Data

- Level of training required

- Availability of equipment and supplies 
- Health and safety concerns (collected by the International Union of Operating Engineers[IUOE])

\subsection{TEST EQUIPMENT AND MATERIALS}

The following equipment and materials were supplied by FIU-HCET:

- Enclosure and ventilation system

- Surrogate/material handling equipment

- Utilities as previously stated

- Surrogate materials

- Personnel to monitor instrumentation

- Project oversight

- Sample and data collectors

- A forklift $(6,000 \mathrm{lbs})$

The technology vendor was required to supply the following as part of the subcontract:

- All required equipment and support equipment

- Trained operators

- Job safety analysis for each technology

- Operating procedures

- Media and other materials

- Project manager

- Information required to complete data requirements section

- Transportation of all equipment, materials, and personnel to FIU-HCET

- Per diem for all vendor personnel.

\subsection{SAMPLING AND ANALYSIS}

Information was collected from commercial experience, vendor information, and field testing. Time studies were conducted to collect some of the operational data. The end point condition was then compared to the appropriate standards to document the end point achieved. Field measurements were taken to document secondary waste generation, potential personnel exposure, and other measurable data requirements. Documentation provided by the vendors and interviews with the vendors provided other pertinent information. Table 1 presents the data requirements and the sample collection method.

The technology vendor was responsible for determining and providing information to FIU-HCET on the estimated quantity of secondary waste that was generated and the characterization of that waste. The vendors were provided with the material safety data sheets for the paint products used 
in the development of the surrogates to aid in the characterization determination. FIU-HCET was responsible for managing and disposing of the generated waste.

Table 1.

Data Requirements

\begin{tabular}{|c|c|}
\hline Data Requirements & Sample Collection Method \\
\hline \multicolumn{2}{|c|}{ GENERAL INFORMATION } \\
\hline Technology description & vendor supplied, field inspection \\
\hline Equipment requirements & vendor supplied, field verification \\
\hline \multicolumn{2}{|c|}{ COST DATA } \\
\hline Capital cost for the purchase of equipment & vendor supplied \\
\hline Utility cost & $\begin{array}{l}\text { vendor supplied, measurement of fuel used, gallons of } \\
\text { water used (flow meter), electric meter calculation }\end{array}$ \\
\hline Maintenance cost & vendor supplied \\
\hline Unit/operating cost & $\begin{array}{l}\text { vendor supplied, generated from operational data } \\
\text { calculations }\end{array}$ \\
\hline \multicolumn{2}{|c|}{ OPERATIONAL DATA } \\
\hline Production rates & time studies \\
\hline End point achieved & comparison to known standards \\
\hline Labor classification & vendor supplied, field verification \\
\hline Limitations & vendor supplied, field inspection \\
\hline Utility requirements & vendor supplied, field verification \\
\hline Power consumption calculations & field calculation \\
\hline Utility requirements & field inspection \\
\hline Environmental conditions & vendor supplied, field inspection \\
\hline Secondary waste management & vendor supplied, field inspection \\
\hline Physical condition of secondary waste & field observation \\
\hline Quantity of media used & field calculation \\
\hline Volume of secondary waste & field calculation \\
\hline Characteristics of media & media material safety data sheet \\
\hline Weight of secondary waste & field measurement \\
\hline Equipment portability & vendor supplied, field verification \\
\hline Measurement of fuel used & field calculation \\
\hline Operation/maintenance requirements & vendor supplied, field verification \\
\hline \multicolumn{2}{|c|}{ IMPLEMENTATION DATA } \\
\hline Level of training required & vendor supplied \\
\hline Availability of equipment and supplies & vendor supplied, verification \\
\hline Health and safety concems & vendor supplied, IUOE* \\
\hline
\end{tabular}

* International Union of Operating Engineers 


\subsection{DEVIATIONS}

The test plan for this project called for four hours of continuous operation for each type of surrogate being tested. The PCRS-7 technology was the only technology that did not follow this format. The four hours of continuous testing was modified for the PCRS-7 because of the nature of this technology. Instead of subjecting this technology to the standard four hours of continuous testing, HCET provided a predetermined number of painted I-beams and plates. Ten painted plates and ten I-beams were provided, and the time necessary for application of the material to the surrogates and its removal from the surrogates was recorded. The time the PCRS-7 remained on the surrogates was approximately 24 hours, but this time was not counted in the determination of the production rate. The PCRS-7 technology operators only attempted to remove the coating from the painted I-beams and plates. They did not attempt to remove rust from the rusted surrogates because they did not think the technology would remove the rust. 


\subsection{TECHNOLOGY RECOMMENDATIONS}

The intent of this section is to review the operation of each of the technologies tested and recommend ways to improve the technology based on the test results. It is important to note that some of the recommended changes may improve the system in one area of operation but adversely impact the technology's ability to excel in another area.

\subsection{PEGASUS COATING REMOVAL SYSTEM (PCRS-7)}

This technology did not prove to be well adapted for a nuclear environment. The PCRS-7 was able to successfully remove the coating from all ten coated I-beam surrogates, but it had difficulty removing the coating from the coated steel plates. This difficulty can be attributed to the different types of coating used for these two surrogate types. Section 3.1.2, "Surrogate Selection and Preparation," describes the types of coating used on these surrogates. By looking at the results, it can be concluded that the PCRS-7 works well for normal types of paint, such as the one on the Ibeams, but it does not work very well on tougher types of coating, such as the epoxy coating used on the plates. This technology could be further improved by using a spray gun to apply the chemical instead of applying it directly from the 5-gallon bucket onto the surface of the surrogates as was done for this demonstration. In addition, the removal process can be improved since the method that was used in this demonstration proved to be messy, difficult, and cumbersome for the worker. A better removal technique should be developed if this technology is used in a contaminated area.

\subsection{NELCO PORTA SHOT}

This technology proved to be well adapted for a nuclear environment, but some additional upgrades can enhance this technology's performance. A better seal around the Nelco Porta Shot ${ }^{\text {th }}$ unit can eliminate or minimize the amount of steel shot flying out of the unit. This shot can become a serious projectile hazard for the worker and for anyone observing the deployment of this technology. In addition, a better, stronger vacuum system should have been used to collect the steel shot. The vendor used a Wet-Vac unit to collect and recycle the shot, but this unit was not able to collect all the shots. The steel shot ended up on the floor of the test chamber and constituted a slipping hazard for the worker. The design of the Nelco Porta Shot ${ }^{\text {th }}$ unit can also be improved from an ergonomic perspective; the workers complained about the trigger mechanism, claiming that holding the trigger became increasingly difficult during the four hours of consecutive operation for each surrogate. This problem could be solved by increasing the dimensions of the trigger and distributing the pressure point to the rest of the operator's hand.

\subsection{ADVANCE RECYCLABLE MEDIA SYSTEM (ARMS"')}

This technology proved to be well adapted for a nuclear environment, but, as with the other technologies, this one can also be improved in certain areas. The ARMS ${ }^{\text {tx }}$ used aluminum oxide media to remove the coating and rust from the surrogates. The removal process was achieved by 
using an open blast method where the media is propelled to the surrogates' surface using compressed air. The media expands and contracts once it touches the surfaces, thereby trapping the paint/rust and contaminants, after which the media falls to the floor. The collection method used by the vendor entailed gathering the media by using a push broom and shoveling it into a trash can. The trash can is then emptied into the sifter unit. It is highly recommended that a better collection system be designed so that the media can be collected without the assistance of an operator. A vacuum collection system can enhance the collection method and minimize workers' exposure to the contaminated media.

\subsection{YAG ERASER ${ }^{\text {T⁄ }}$}

This technology proved to be well adapted for a nuclear environment, although the system used for the demonstration was a 150-watt demonstration-sized unit fabricated by LASERTRONICS and not a production unit. The system achieved low production rates, but, with a larger production unit, we believe that this technology can achieve higher production rates. The vacuum collection system will require modification and upgrading if a larger production unit is built. The system proved to be extremely mobile and very quick to set up. Additional developmental work needs to be performed before this unit is deployed in a nuclear environment. 


\subsection{LESSONS LEARNED}

The study did not specify a required end point for a technology to meet. The vendors were asked to optimize all the operating technologies to achieve the best end point condition. As expected, this optimal end point condition varied among the technologies. Optimizing the operating parameters was an unusual request from the vendors' perspectives. After discussions with the vendors, the goal of optimizing the technology was met.

The testing of these technologies was carried out under non-nuclear conditions. For FY97, the four technology tests varied in deployment, production, and waste generation. The PCRS-7, NELCO Porta Shot Blast" and ARMS ${ }^{\text {tw }}$ were fully developed, commercially available technologies, but the YAG ERASER ${ }^{\text {nt }}$ was a prototype laser ablation system, which is evident from its low production rate. This technology was tested anyway, realizing that it was under development. The comparison of this innovative technology with the other three commercially available technologies may not be fair, but all technologies were compared under identical standard non-nuclear conditions. A production unit of the YAG ERASER ${ }^{\text {Tx }}$ would have been better suited for this 16-hour test, but this unit was not available. 


\subsection{FY96 \& FY97 TECHNOLOGY ASSESSMENTS}

During the first year of this project, two commercially available technologies were tested. These technologies were Pentek's mechanical scabbling system and LTC Americas PTC-6 system. During the second year of this project, four additional technologies were tested at HCET. These four technologies were Pegasus's PCRS-7, NELCO's Porta Shot Blast ${ }^{\text {t4 }}$ JHJ-2000, Pierpoint Environmental's ARMS ${ }^{n}$, and EXITECH/LASERTRONIC'S YAG ERASER ${ }^{n}$. The rest of the technologies presented in Table 2 will be demonstrated during FY98 under the project entitled "Decision Analysis Science Modeling for Application and Fielding Selection Applied to Metal and Masonry." In addition, the information collected during the technology demonstrations has been input into HCET's Multi-Media Information System for Decontamination (MISD). A multicriteria decision-making technique (MODM) has been created and implemented, making use of the MISD data. A Final Report entitled "Decision Analysis System for Selection of Appropriate Decontamination Technologies" has been developed for FY97.

Table 2.

Technologies for Metal Decontamination FY96 and FY97

\begin{tabular}{|l|l|l|c|}
\hline & Technology Name & Company & Expected Demonstration Date \\
\hline 1 & Mechanical Scarification & Pentek Inc. & Completed FY96 \\
\hline 2 & PTC-6 System & LTC Americas & Completed FY96 \\
\hline 3 & PCRS-7 Chemical Process & Pegasus International & Completed FY97 \\
\hline 4 & Centrifugal Shot Blasting & Pegasus International & Completed FY97 \\
\hline 5 & $\begin{array}{l}\text { Advanced Recyclable Media } \\
\text { System (ARMS }\end{array}$ & $\begin{array}{l}\text { Aerojet, } \\
\text { Pierpoint Environmental }\end{array}$ & Completed FY97 \\
\hline 6 & Laser Ablation & EXITECH/LASERTRONIC & Completed FY97 \\
\hline 7 & Laser Ablation & F2 Associates & TBD* \\
\hline 8 & Flashlamp & Polygon/Parsons & TBD \\
\hline 9 & CO $_{2}$ with Vacuum & Non-Destructive Cleaning & TBD \\
\hline 10 & $\begin{array}{l}\text { Ultra High Pressure } \\
\mathrm{H}_{2} \mathrm{O} \text { with Vacuum }\end{array}$ & AEA, Mota Corp. & TBD \\
\hline
\end{tabular}

* To be determined. 
Bigos, J., 1954. Steel Structures Painting Manual, Steel Structures Painting Council, Vol. 1 \& 2. Bigos, J., 1954. Good Painting Practice, Steel Structures Painting Council.

Ebadian, M.A. and Lagos, L.E., 1995. Analysis of Potential Surface Blasting Decontamination Technologies for Structural Steel, Final Report, Hemispheric Center for Environmental Technology (HCET), Florida International University, Miami, FL.

Environmental Protection Agency, 1994. Guide to Cleaner Technologies Organic Coating Removal, Washington, D.C.

FERMCO, 1994. Operable Unit 3 Treatability Study Work Plan, FERMCO, Cincinnati, OH.

Steel Structures Painting Council, 1993. Standard Method of Evaluating Degree of Rusting on Painted Steel Surfaces, Steel Structures Painting Council, Pittsburg, PA.

Steel Structures Painting Council, 1991. Surface Preparation Specifications, Steel Structures Painting Council, Pittsburg, PA.

Steel Structures Painting Council, 1992. Visual Standard for Abrasive Blast Cleaned Steel, Guide and Standard, Pittsburg, PA.

United States Department of Energy (DOE), 1994. Decommissioning Handbook, DOE/EM0142P, United States Department of Commerce, Springfield, VA.

United States Department of Energy (DOE), 1993. Oak Ridge National Technology Logic Diagram, ORNL/M2751, United States Department of Energy, Oak Ridge, TN.

United States Department of Energy (DOE), January 1994. Idaho National Engineering Laboratory Decontamination and Decommissioning Technology Logic Diagram, EGGWTD-11104, United States Department of Energy, Idaho Falls, Idaho.

United States Department of Energy (DOE), June 1995. Decontamination and Decommissioning Focus Area Technology Summary, DOE/EM-0253, United States Department of Energy, Morgantown, WV. 


\section{JOB SAFETY ANALYSIS}

\section{Job Safety Analysis}

The Job Safety Analysis (JSA) forms filled out by the technology vendors are presented in this section. The PCRS-7 JSA form is presented in Figure 15; the NELCO Porta Shot Blast ${ }^{\text {th }}$ (JHJ2000) JSA form is presented in Figure 16, the ARMS ${ }^{\mathrm{Tx}}$ JSA form is presented in Figure 17, and the Laser-Ablation JSA form is presented in Figure 18. 
Figure 15. PCRS-7's JSA

JOB SAFETY ANALYSIS

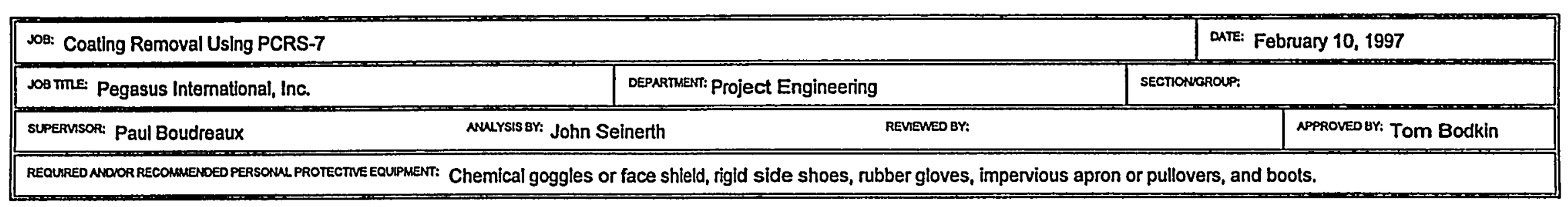

\begin{tabular}{|c|c|c|}
\hline $\begin{array}{l}\text { SEQUENCE OF BASIC } \\
\text { JOB STEPS }\end{array}$ & $\begin{array}{l}\text { POTENTIAL ACCIDENTS } \\
\text { OR HAZARDS }\end{array}$ & RECOMMENDED SAFE JOB PROCEDURE \\
\hline $\begin{array}{l}\text { Arrange polyethylene tarpaulins and disposal } \\
\text { contalners around the work area. }\end{array}$ & Possible lifting injuries. & Ensure drums are moved with hand truck or lifted with safety practices. \\
\hline $\begin{array}{l}\text { Remove any loose debris with a large vacuum } \\
\text { cleaner. }\end{array}$ & Possible electric shock. & $\begin{array}{l}\text { Ensure vacuum cleaner electrical cords and extensions are in proper working } \\
\text { condition. Never operate device if status of device is questionable (i.e. frayed wires, } \\
\text { inconsistent motor vibrations). }\end{array}$ \\
\hline Open the drum containing the PCRS chemical. & Physical injury from improperly applied prying force. & $\begin{array}{l}\text { Care should be taken when opening drums of PCRS. Prying force should be away } \\
\text { from body and clear of any obstructions. }\end{array}$ \\
\hline Apply the PCRS chemical. & Exposure to PCRS chemical. & $\begin{array}{l}\text { Wear proper PPE. Obey implemented engineering controls. Review and } \\
\text { familiarize self with MSDS sheets to gain proper understanding of chemical. }\end{array}$ \\
\hline Apply fibrous laminated cloth. & Physical injury from knife blades. & $\begin{array}{l}\text { Care should be taken when cutting sheels to size. Cut on rigid surface. Close blade } \\
\text { when finished. }\end{array}$ \\
\hline $\begin{array}{l}\text { Remove the applied chemical and substrate from } \\
\text { surface with scrapers. }\end{array}$ & Exposure to chemical. & $\begin{array}{l}\text { Maintain proper use of PPE. Immediately wash any chemical from exposed skin } \\
\text { with soap and water. }\end{array}$ \\
\hline Vacuum any remaining debris with vacuum cleaner. & P'ossible electric shock. & $\begin{array}{l}\text { Water is used in conjunctive step. Cure should be taken to sepurate the electrical } \\
\text { wires and vacuum cleaner from damp sponges and buckets. }\end{array}$ \\
\hline Clean scrapers, brushes, and other tools with water. & Exposure to PCRS chemicals. & $\begin{array}{l}\text { Wash hands thoroughly with soap and water. Avoid splashing water-chemical } \\
\text { mixture to ensure no careless exposure to skin or eyes. }\end{array}$ \\
\hline $\begin{array}{l}\text { Deposit material (PCRS and removed surrogate) } \\
\text { into drums for disposal. }\end{array}$ & Physical injury due to improper lifting. & $\begin{array}{l}\text { Do not overload shovels ensuring load is manageable. Lift with knees to ensure no } \\
\text { strain on back. }\end{array}$ \\
\hline $\begin{array}{l}\text { Leave drums and empty PCRS containers to dry } \\
\text { until contents are solid. }\end{array}$ & Exposure to PCRS chemicals. & $\begin{array}{l}\text { If left unattended, post placards properly around job site to ensure no exposure to } \\
\text { other personnel. Properly rope off area. }\end{array}$ \\
\hline $\begin{array}{l}\text { Dispose of drums and containers per locul } \\
\text { regulations }\end{array}$ & $\begin{array}{l}\text { Exposure to PCRS chemicals. Physical injury due to } \\
\text { improper lifting. }\end{array}$ & $\begin{array}{l}\text { Ensure proper lPEE is wom. Practice safe lining procedures. If drums are too heavy } \\
\text { or cumbersome, get assistance, forklin or hand truck. }\end{array}$ \\
\hline
\end{tabular}


Figure 16. NELCO Porta Shot Blast's JSA

\section{JOB SAFETY ANALYSIS}

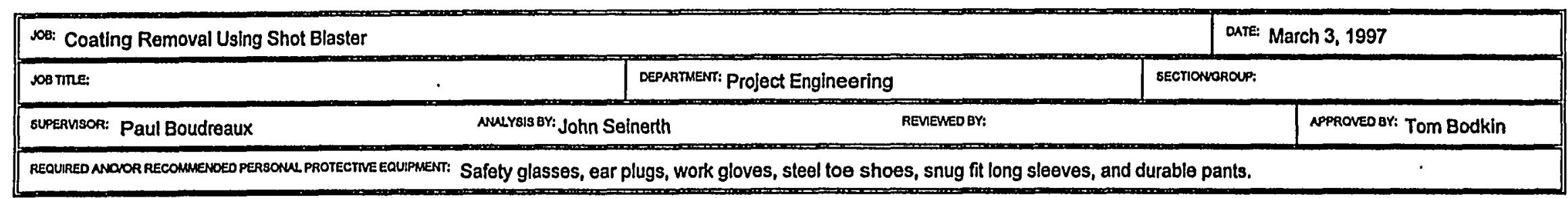

\begin{tabular}{|c|c|c|c|}
\hline & $\begin{array}{l}\text { SEQUENCE OF BASIC } \\
\text { JOB STEPS }\end{array}$ & $\begin{array}{l}\text { POTENTIAL ACCIDENTS } \\
\text { OR HAZARDS }\end{array}$ & RECOMMENDED SAFE JOB PROCEDURE \\
\hline & $\begin{array}{l}\text { Remove any loose debris with a vacuum } \\
\text { cleaner. }\end{array}$ & 1. Possible electric shock. & $\begin{array}{l}\text { 1. Ensure vacuum cleaner electrical cords and extensions are in proper working } \\
\text { condition. Never operate device if status of device is questionable (l.c. frayed } \\
\text { wires, inconsistent motor vibrations) }\end{array}$ \\
\hline 2. & Connect vacuum cleaner to shot blaster. & 2. Possible physical injury. & $\begin{array}{l}\text { 2. Ensure both vacuum cleaner and shot blaster are not plugged in. Watch pinch } \\
\text { points when connecting lines. }\end{array}$ \\
\hline 3. & Close the shot valve on the shot blaster. & 3. Possible physical injury due to fall hazards. & $\begin{array}{l}\text { 3. Ensuring that the shot valve is closed will not allow any unwanted shot to } \\
\text { disperse on the walking surface. }\end{array}$ \\
\hline 4. & $\begin{array}{l}\text { Set the blast seals so they are firm against the } \\
\text { blast surface and fill hopper with shot. }\end{array}$ & 4. Possible physical injury. & $\begin{array}{l}\text { 4. It is cnucial to properly set the blast seals so no propelled shot will be striking } \\
\text { away from the wall }\end{array}$ \\
\hline 5. & $\begin{array}{l}\text { Power-up the shot blaster and adjust the } \\
\text { amount of shot thrown. }\end{array}$ & $\begin{array}{l}\text { 5. Possible physical injury from electrical shock or } \\
\text { propelled shot. }\end{array}$ & $\begin{array}{l}\text { 5. Ensure electrical cables are in proper working condition. Wear proper PPE at } \\
\text { all times. }\end{array}$ \\
\hline 6. & $\begin{array}{l}\text { Run shot blaster across surface in an orderly } \\
\text { progression. }\end{array}$ & $\begin{array}{l}\text { 6. Possible physical injury due to blade failure or } \\
\text { propelled shot. }\end{array}$ & $\begin{array}{l}\text { 6. Maintain proper use of PPE. Personnel should not be positioned in front of or } \\
\text { to the side of the blast housing in case of blade fallure. Never operate blaster } \\
\text { in elevated position. Keep hands away from moving parts. Never operate } \\
\text { machines on wet surfaces. Operate machine in proper ergonomic position. }\end{array}$ \\
\hline 7. & Empty the dust collector. & 7. Possible dust exposure. & 7. Open canister slowly in a well ventilated area. Wear proper PPE. \\
\hline 8. & Pack equipment. & 8. Physical injury due to improper lifting techniques. & 8. Lift with knees to ensure no strain of back. \\
\hline
\end{tabular}


Figure 17. ARMS's JSA

JOB SAFETY ANALYSIS

\begin{tabular}{|c|c|c|c|}
\hline J08: Media Blasting for Surface Removal on Metal & & DATE: & \\
\hline JOO TME: & DEPARTMENT: & SECTONGROUP: & \\
\hline SUPERMSOR: Dell V. ReUSS & REVEWED BY: & & APPROVEOBY: \\
\hline
\end{tabular}

\section{Operation of Sifter}

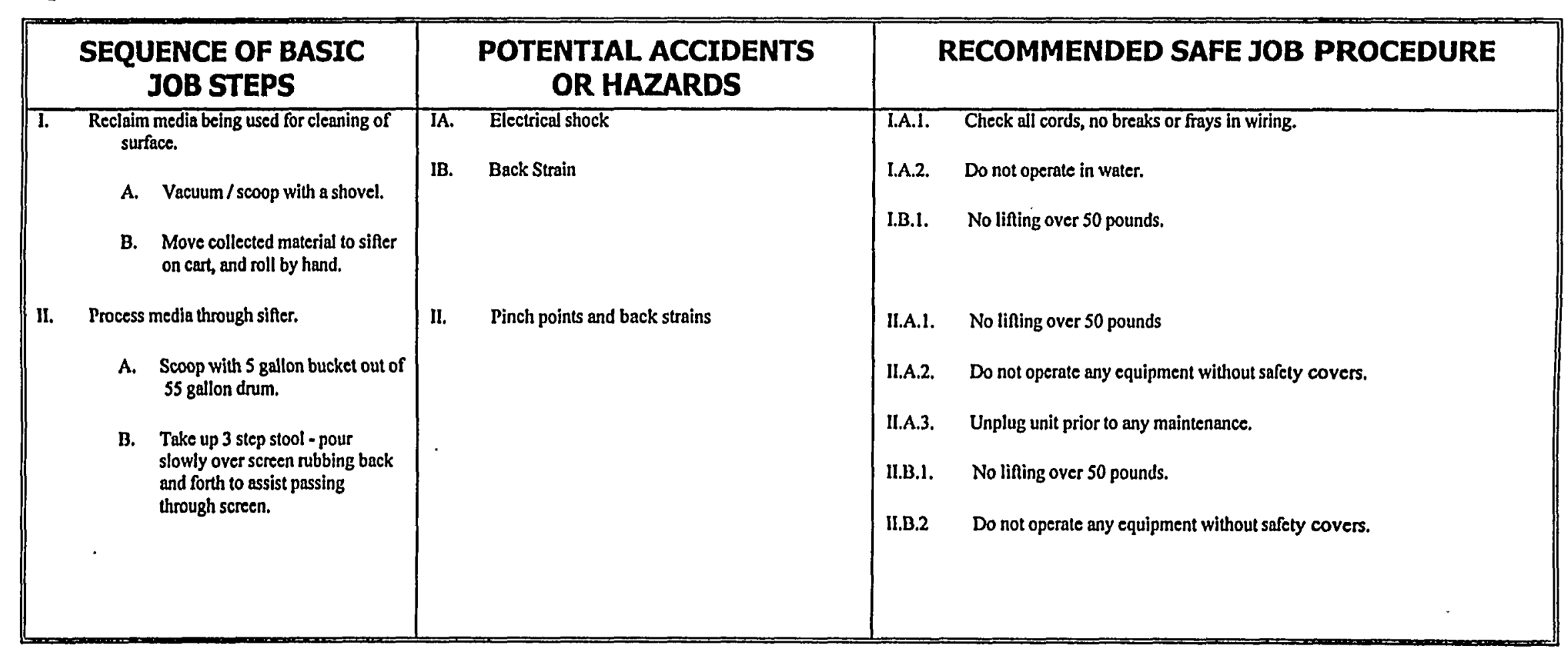


Operation of Feed Unit

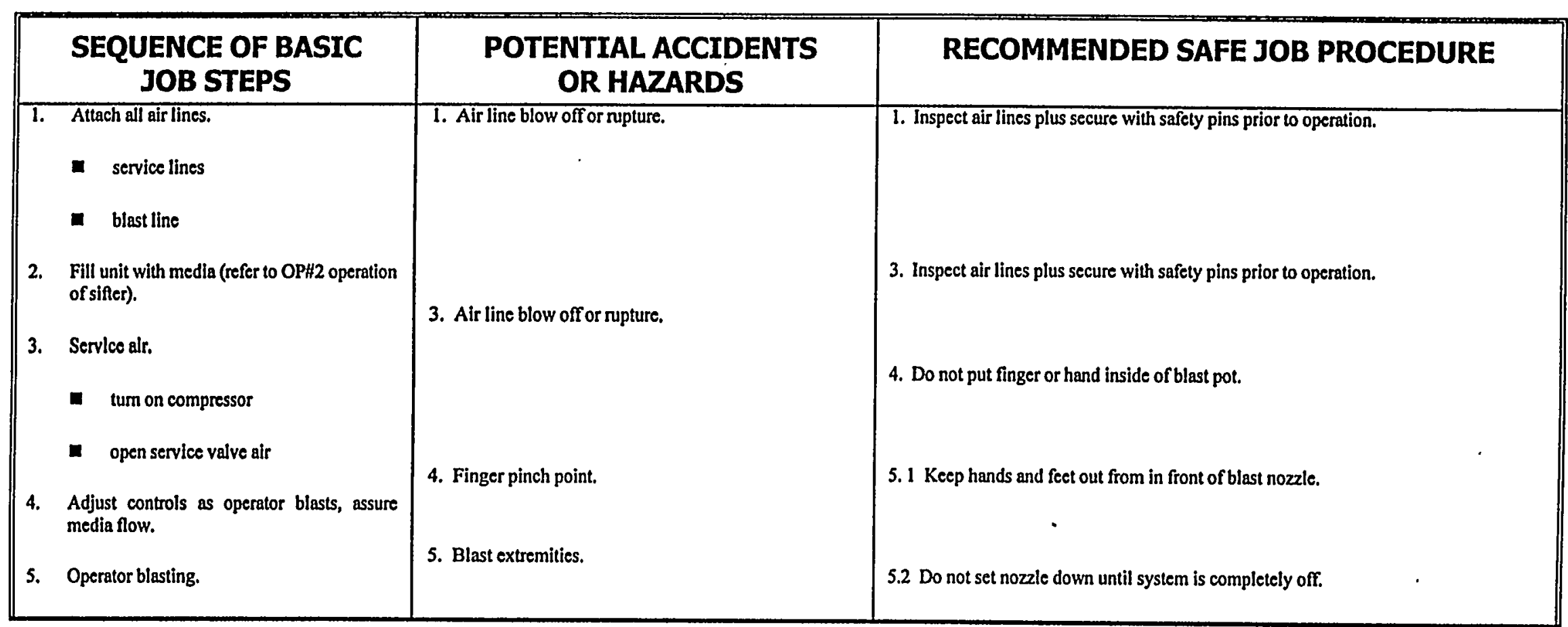


Operation of Vapor Generator

\begin{tabular}{|c|c|c|}
\hline $\begin{array}{c}\text { SEQUENCE OF BASIC } \\
\text { JOB STEPS }\end{array}$ & $\begin{array}{c}\text { POTENTIAL ACCIDENTS } \\
\text { OR HAZARDS }\end{array}$ & RECOMMENDED SAFE JOB PROCEDURE \\
\hline 1. Hook up electrical. & $\begin{array}{l}\text { 1. Electrical shock. } \\
\qquad \begin{aligned} \cdot+! \\
\vdots\end{aligned}\end{array}$ & $\begin{array}{l}1.1 \text { Inspect all cords for frayed ends or culs. } \\
\vdots \\
1.2 \text { Do not place cords in water. }\end{array}$ \\
\hline 3. Hook vapor hoso to feed unit. & 3. Rupture of vapor hose. & 3. Inspect vapor line to assuro no cuts or crack. \\
\hline $\begin{array}{l}\text { 4. Tum system on according to OP\#3 operation of } \\
\text { vapor generatos. }\end{array}$ & 4. Over pressure system. & $\begin{array}{l}\text { 4. Assure pop-off is not bypassed and if system were to over pressurize the vapor will } \\
\text { release in a safe manner. }\end{array}$ \\
\hline
\end{tabular}

1 
Figure 18. Laser Ablation's (YAG ERASER ${ }^{\text {TM}}$ ) JSA

JOB SAFETY ANALYSIS

\begin{tabular}{|c|c|c|}
\hline NOB: FIU/HCET Demonstration & & DATE: July 2, 1997 \\
\hline JOB rILE: ERASER Operator & DEPARTMENT: 1300 & SECTIONAROUP: 2790 / ERASER \\
\hline SUPERVSOR: J.R.F & REMEWEO OY: J. T. & APPROVED BY: \\
\hline
\end{tabular}

\begin{tabular}{|l|l|l|}
\hline SEQUENCE OF BASIC JOB STEPS & $\begin{array}{c}\text { POTENTIAL ACCIDENT } \\
\text { OR HAZARDS }\end{array}$ & \multicolumn{1}{|c|}{ RECOMMENDED SAFE JOB PROCEDURE } \\
\hline SETUP & $\begin{array}{l}\text { 1. Electrical shock when hooking up power. } \\
\text { 2. Eye damage from exposed laser light. }\end{array}$ & $\begin{array}{l}\text { 1. Insure power is tumed off to junction box mounted on the ERASER trailer. } \\
\text { 2. Follow job-site safety procedures. } \\
\text { 3. User laser light eyeglasses whenever the laser case is removed, work is being } \\
\text { performed on the work head, or any time the work head is not on the work surface } \\
\text { when the laser is on. } \\
\text { 4. Follow job-site personnel protection requirements. } \\
\text { 5. Use plastic bags and tubing to prevent additional contamination of equipment. }\end{array}$ \\
OPERATION & $\begin{array}{l}\text { 1. Personnel hazard from mis-operation or } \\
\text { failure of interlock devices. }\end{array}$ & $\begin{array}{l}\text { 1. Follow job-site safety procedures. } \\
\text { 2. Follow laser safety procedures. } \\
\text { 1. Electrical shock when removing power. } \\
\text { 1. Insure power is turned off to junction box. } \\
\text { 2. Fequired job-site, personnel protection. }\end{array}$ \\
\hline
\end{tabular}




\section{APPENDIX B}

\section{TECHNOLOGY DATA REQUIREMENTS: DEFINITIONS}




\section{TECHNOLOGY DATA REQUIREMENTS: DEFINITIONS}

\section{B.1 TECHNOLOGY OVERVIEW}

This section presents a summary of each technology tested. The technologies are described by operating principles and equipment used and by the benefits and limitations of each technology. Capital, equipment, and costs are described.

\section{Applicable Surface}

The first item in this line identifies the surface type and configuration (e.g., structural steel). The second item indicates the end point achieved for this group of technologies. It is important to note that the end point achieved during the review of the technologies is presented to ensure that the technologies are reviewed on an equal basis.

\section{Technology Class}

Established databases were used for categorizing and performing the initial screening of technology types. These databases provided a screening based on the applicability of a technology to a given material and contaminant. These databases included:

- DOE/EM-0142P Decommissioning Handbook

- ORNL/M-2751 Oak Ridge National Laboratory Tẹchnology Logic Diagram

- EGG-WTD-11104 Idaho National Engineering Laboratory Decontamination and Decommissioning Technology Logic Diagram

- Fernald Environmental Restoration Management Corporation (FERMCO), 1994, Operable Unit 3 Treatability Study Work Plan, FERMCO, Cincinnati

- Remedial Action Program Information Center (RAPIC) database.

\section{Estimated Capital Cost}

The estimated capital cost represents a range of approximate capital costs from a technology classification perspective. The technology classification perspective uses information provided by multiple technology vendors. The equipment requirements report provides costs for the technologies tested. 


\section{Technology Class Description}

The technology class description provides an introduction to the broad technology category. Details such as a description of the media used, how the media is propelled, a description of vacuum system (if. used), and the process by which the paint/contaminant is removed are provided.

\section{Benefits}

Benefits were obtained by performing a literature search of the individual technologies and by conducting field demonstrations. If a conflict existed between published information and the field demonstrations, the data collected in field testing were used. This section provides an overview of the potential benefits.

\section{Limitations}

Limitations were obtained by performing a literature search of the individual technologies and by conducting field demonstrations. If a conflict existed between published information and the field demonstrations, the data collected in field testing were used. This section provides an overview of the potential limitations.

\section{B.2 OPERATIONAL PARAMETERS}

This section describes the operational parameters collected during the testing of each technology. The data described were observed and measured for all technologies. Vendor information was also used and verified by field measurements.

\section{Technology Name}

The specific name of the technology as obtained from the technology vendor is provided.

\section{Technology Class}

Established databases were used for categorizing and performing the initial screening of technology types. These databases provided a screening based on the applicability of a technology to a given material and contaminant. These databases included:

- DOE/EM-0142P Decommissioning Handbook

- ORNL/M-2751 Oak Ridge National Laboratory Technology Logic Diagram

- EGG-WTD-11104 Idaho National Engineering Laboratory Decontamination and Decommissioning Technology Logic Diagram

- Fernald Environmental Restoration Management Corporation (FERMCO), 1994, Operable Unit 3 Treatability Study Work Plan, FERMCO, Cincinnati

- Remedial Action Program Information Center (RAPIC) database. 


\section{Labor Classification}

Standard labor classifications are used to determine the personnel required. These classifications are equipment operators, technicians, and field engineers. This represents the minimum number of personnel required to operate the equipment. The number of personnel needed to operate equipment in a contaminated environment is not calculated.

\section{Environmental Conditions}

A description of the work environment created by the operation of the technology is provided. These descriptions include: presence or absence of visible emissions, water fog created in enclosure, visible air turbulence, etc.

\section{Production Rate}

The production rate was calculated by measuring and calculating the number of square feet treated and dividing this result by the number of operating hours required to do it. The operating hours encompassed all factors associated with the vendor operation of the technology, like operating time, minor maintenance activities (e.g., cleaning a nozzle or changing a vacuum head), and equipment adjustment. If multiple technologies were used on the area, individual production rates were calculated.

\section{Volume of Secondary Waste}

The volume of secondary waste generated was determined by counting the number of waste drums, determining the average volume of the waste drums, and by dividing by the operating time. The operating hours consisted of all factors associated with the vendor's operation of the technology, like operating time, minor maintenance activities (e.g., cleaning a nozzle or changing a vacuum head), and equipment adjustment. The value of secondary waste includes the removed paint and the spent media. The input flow rate was used for the secondary waste volume. No effort was made to separate the primary waste (i.e., removed paint or rust) from the secondary waste (i.e., media, filters, etc.).

\section{Characteristics of Secondary Waste}

This section describes the physical condition of the secondary waste as determined by visual observation. These observations include: 1) fine powder with no observable difference from the media and the paint rust and 2) small pieces of media mixed with paint or rust.

\section{B.3 UTILITYIMEDIA REQUIREMENTS}

This section describes the utility required by each technology, the type of media, the cost of the media, and the quantity of media required on a per-unit basis. The data described were observed and measured for all technologies. Vendor information was also used and verified by field measurements. 


\section{Technology Name}

The specific name of the technology as obtained from the vendor is provided.

\section{Type of Media}

This section presents the general classification of the media used. Specific grades of media are not recorded. The type of media varied with the required end point to be achieved.

\section{Media Cost}

Vendor information was used to determine the cost of the media per pound. In the case of the technologies that use bits, the cost for a complete bit replacement was divided by the number of operating hours required before bit replacement. The bit replacement cost and the number of operating hours required before bit replacement were obtained from the vendor.

\section{Media Quantity}

The quantity of media required per hour of operation was obtained from the vendor.

\section{Utility Requirements}

The types of utilities required to operate the technology are presented in this section. The utilities used during the field testing are shown. In many cases, optional power sources are available for each type of equipment. Not shown in the tables are utilities needed to operate the containment, and ventilation system or any support equipment.

\section{B.4 EQUIPMENT REQUIREMENTS REPORT}

This table provides specific information related to the technologies tested. This includes a specific description of the technology name, utility requirements, capital cost, operating/maintenance requirements, equipment portability, and availability of the equipment.

\section{Technology Name}

The specific name of the technology as obtained from the vendor is provided.

\section{Technology Class}

Established databases were used for categorizing and performing the initial screening of technology types. These databases provided a screening based on the applicability of a technology to a given material and contaminant. These databases included:

- DOE/EM-0142P Decommissioning Handbook

- ORNL/M-2751 Oak Ridge National Laboratory Technology Logic Diagram

- EGG-WTD-11104 Idaho National Engineering Laboratory Decontamination and Decommissioning Technology Logic Diagram 
- Fernald Environmental Restoration Management Corporation (FERMCO), 1994, Operable Unit 3 Treatability Study Work Plan, FERMCO, Cincinnati

- Remedial Action Program Information Center (RAPIC) database.

\section{Description}

This section provides a general description of the technology classification as well as a description of the specific technology tested.

\section{Utility Requirements}

The types of utilities required to operate the technology are presented. The utilities used during the field testing are shown. In many cases, optional power sources are available for each type of equipment. Utilities needed to operate the containment and ventilation system and support equipment are not reflected here.

\section{Capital Cost}

Capital cost represents the purchase cost of the technologies tested. These figures were obtained from the technology vendors.

\section{Operating/Maintenance Requirements}

The operational/maintenance requirements give an account of the types of operational and maintenance activities performed during the hours of operation.

\section{Equipment Portability}

Equipment portability is broken down into four categories. These categories include: equipment that can be moved by one person; equipment that requires two people to move; equipment that requires a forklift to move; or trailer-mounted equipment.

\section{Availability of Equipment}

The availability of equipment and supplies was obtained from the individual technology vendors. We differentiate long-lead procurement items from equipment and supplies that are off-the-shelf items.

\section{B.5 HEALTH AND SAFETY}

This section presents information indicating some of the potential health and safety hazards related to each technology. These health and safety considerations were observed during the duration of each test. This information was developed by the International Union of Operating Engineers (IUOE). A detailed report is available from the IUOE for each of the technologies tested. 
DATA SECTION 
Tabl

Technolog

\begin{tabular}{|c|c|c|c|c|}
\hline Technology & Technology Description & $\begin{array}{l}\text { Estimated } \\
\text { Capital Cost }\end{array}$ & Benefits & Limitations \\
\hline $\begin{array}{l}\text { Name: } \\
\text { Pegasus Chemical } \\
\text { Coating Removal } \\
\text { System } \\
\text { Classification: } \\
\text { Coating Removal } \\
\text { Model: } \\
\text { PCRS-7 }\end{array}$ & $\begin{array}{l}\text { PCRS-7 is a chemical coating removal method } \\
\text { that has been developed by Pegasus } \\
\text { International, Inc. for the removal of } \\
\text { chemically resistant coatings (i.e., epoxies, } \\
\text { urethanes, chlorinated, rubber, elastomeric, } \\
\text { aluminum, vinyls, mastics, and most marine } \\
\text { coatings). The PCRS-7 is an organic solvent } \\
\text { mixture, light beige in color, with a slight } \\
\text { sweet odor, and is supplied in 1-, 5-, or 55-gal } \\
\text { plastic buckets. Depending on the substrate and } \\
\text { operating conditions, PCRS-7 is applied by } \\
\text { pouring directly from the bucket or from a } \\
\text { smaller container, and long- and/or short- } \\
\text { handled spreaders or trowels are used to } \\
\text { distribute it evenly across the surface. It can } \\
\text { also be applied by using a sprayer to spray the } \\
\text { coating on the surface. Once distributed, the } \\
\text { chemical is covered by a single layer of white } \\
\text { freezer paper. Removal of the PCRS-7 and } \\
\text { primary waste is achieved by lifting up and } \\
\text { removing the paper, followed by scraping the } \\
\text { surface using trowels and/or large plastic } \\
\text { shovels. }\end{array}$ & No capital cost. & $\begin{array}{l}\text { Can remove coatings } \\
\text { from complex } \\
\text { surface geometries } \\
\text { that blasting } \\
\text { equipment cannot } \\
\text { reach. } \\
\text { Requires no capital } \\
\text { purchase. } \\
\text { No maintenance } \\
\text { costs are incurred. } \\
\text { No special service is } \\
\text { required following } \\
\text { successful coating } \\
\text { removal. Additional } \\
\text { coatings may be } \\
\text { applied after a } 24 \\
\text { hour drying period. }\end{array}$ & $\begin{array}{l}\text { Limited to applied } \\
\text { coating characteristi } \\
\text { Surface must be clea } \\
\text { and dry. } \\
\text { Removal efficiency } \\
\text { reduced below a } \\
\text { temperature of } 40^{\circ} \mathrm{F} \\
\text { Removal efficiency } \\
\text { reduced under condi } \\
\text { favorable for accele } \\
\text { evaporation. To } \\
\text { compensate for this, } \\
\text { laminated fibrous cl } \\
\text { or freezer paper can } \\
\text { used to cover the su } \\
\text { of the applied PCR } \\
\text { decrease the evapor } \\
\text { rate. }\end{array}$ \\
\hline $\begin{array}{l}\text { Name: } \\
\text { NELLCO Porta Shot } \\
\text { Blast }^{\text {ne }} \\
\text { Classification: } \\
\text { Steel Abrasive } \\
\text { Blasting } \\
\text { Model: } \\
\text { JHJ-2000 }\end{array}$ & $\begin{array}{l}\text { Hand-held portable steel shot blaster. Blast } \\
\text { pattern: } 1 \text { in. } \times 1.7 \text { in. The debris accumulates } \\
\text { in the dust collector, and the shot accumulates } \\
\text { in the hopper after rebounding from the work } \\
\text { surface. Gravity then pulls the shot into the } \\
\text { impeller where it is recycled. Blaster holds } \\
\text { approx. } 2 \mathrm{lb} \text { of shot. }\end{array}$ & $\begin{array}{l}\text { NELCO Porta Shot } \\
\text { Blast }{ }^{\text {mp }} \\
\$ 3,000\end{array}$ & $\begin{array}{l}\text { Shot is continuously } \\
\text { recycled while the } \\
\text { shot feed spout is } \\
\text { open. } \\
\text { Machine can be } \\
\text { operated either } \\
\text { forward or backward } \\
\text { while blasting. } \\
\text { Can be used on both } \\
\text { concrete and metal } \\
\text { surfaces. } \\
\text { Blast media is } \\
\text { relatively } \\
\text { inexpensive. } \\
\text { This unit can be used } \\
\text { in almost any plane } \\
\text { of operation by } \\
\text { using different } \\
\text { attachments. }\end{array}$ & $\begin{array}{l}\text { Not effective for he } \\
\text { coating removal. } \\
\text { Not recommended } \\
\text { large surface areas. } \\
\text { A severe loss of shy } \\
\text { results when the bly } \\
\text { seals lose contact } \\
\text { the surface. } \\
\text { Does not work on } \\
\text { surfaces. } \\
\text { This technology ha } \\
\text { removal gap of } 1.5 \\
\text { Should not be used } \\
\text { the vicinity of } \\
\text { flammable liquids. }\end{array}$ \\
\hline
\end{tabular}


Techn

\begin{tabular}{|c|c|c|c|c|}
\hline Technology & Technology Description & $\begin{array}{c}\text { Estimated } \\
\text { Capital Cost }\end{array}$ & Benefits & Limitat \\
\hline $\begin{array}{l}\text { Name: } \\
\text { Nd: YAG ERASER } \\
\text { Classification: } \\
\text { Laser }\end{array}$ & $\begin{array}{l}\text { The Nd: YAG ERASER }{ }^{\text {T2 }} \text { technology system } \\
\text { consists of a laser light that ablates coatings } \\
\text { from various surfaces. The intensity and shape } \\
\text { of the light is designed to control and minimize } \\
\text { the damage to the substrate being } \\
\text { decontaminated. A specialized optical fiber } \\
\text { helps transmit the laser light to a hand-held } \\
\text { work head. The work head consists of control } \\
\text { and feedback systems. The control system } \\
\text { allows the operator to adjust the stripping rate } \\
\text { and area of the path of removal, to start and } \\
\text { stop the stripping process, and to provide an } \\
\text { emergency stop function. The feedback systems } \\
\text { provide the operator with a visual } \\
\text { representation of the surface being removed } \\
\text { and the input to the laser control software. The } \\
\text { work head also consists of a vacuum line that } \\
\text { collects any gasses or particles present at the } \\
\text { surface. The vacuum line is connected to a } \\
\text { waste management system, consisting of HEPA } \\
\text { filters and charcoal pellets. }\end{array}$ & $\$ 249,000$ & $\begin{array}{l}\text { The Nd: YAG } \\
\text { ERASER }{ }^{\text {m }} \text { head } \\
\text { weighs only about } 9 \\
\text { lb. Workers are not } \\
\text { fatigued easily. }\end{array}$ & $\begin{array}{l}\text { The strip rate } \\
\text { to about } 31 / 2 \text { in } \\
\text { per pass. } \\
\text { The demonstra } \\
\text { is limited to } 25 \\
\text { the trailer to th } \\
\text { head. The prod } \\
\text { unit is limited } \\
\text { approximately } \\
\text { Not designed } 1 \\
\text { underwater us } \\
\text { Cannot remov } \\
\text { edges due to si } \\
\text { requirement. }\end{array}$ \\
\hline $\begin{array}{l}\text { Name: } \\
\text { ARMS (Advanced } \\
\text { Recyclable } \\
\text { Mechanical System) } \\
\text { Classification: } \\
\text { Sponge blasting }\end{array}$ & $\begin{array}{l}\text { The ARMS }{ }^{\infty} \text { equipment is comprised of a feed } \\
\text { unit and a sifter unit. The feed unit is a portable } \\
\text { pneumatically powered device that propels the } \\
\text { media against the contaminated surface. } \\
\text { Sponge media is manually loaded into a hopper } \\
\text { mounted on top of the feed unit, and is fed to } \\
\text { an auger devise that mixes the cleaning media } \\
\text { with compressed air. The sifter unit is used to } \\
\text { mechanically remove large debris and powdery } \\
\text { residues from the sponge media after use. The } \\
\text { sifter vibrates causing the media to fall } \\
\text { downward through a series of separation } \\
\text { screens to remove the debris from the } \\
\text { recyclable media }\end{array}$ & $\begin{array}{l}\text { ARMS }{ }^{\star} \text { Feed Unit: } \\
\$ 10,800 \\
\text { ARMS } \\
\$ 7,200 \\
\text { ARMS } \\
\text { Generator: } \$ 5,400 \\
\text { Vacuum Cleaner: } \\
\$ 500\end{array}$ & $\begin{array}{l}\text { The reusable media } \\
\text { significantly reduces } \\
\text { the waste generated } \\
\text { per square foot of } \\
\text { surface treated. }\end{array}$ & $\begin{array}{l}\text { System requir } \\
\text { media reloadi } \\
\text { A ventilated c } \\
\text { structure is re } \\
\text { to the dust pa } \\
\text { produced duri } \\
\text { operation }\end{array}$ \\
\hline
\end{tabular}


Utility/Me(

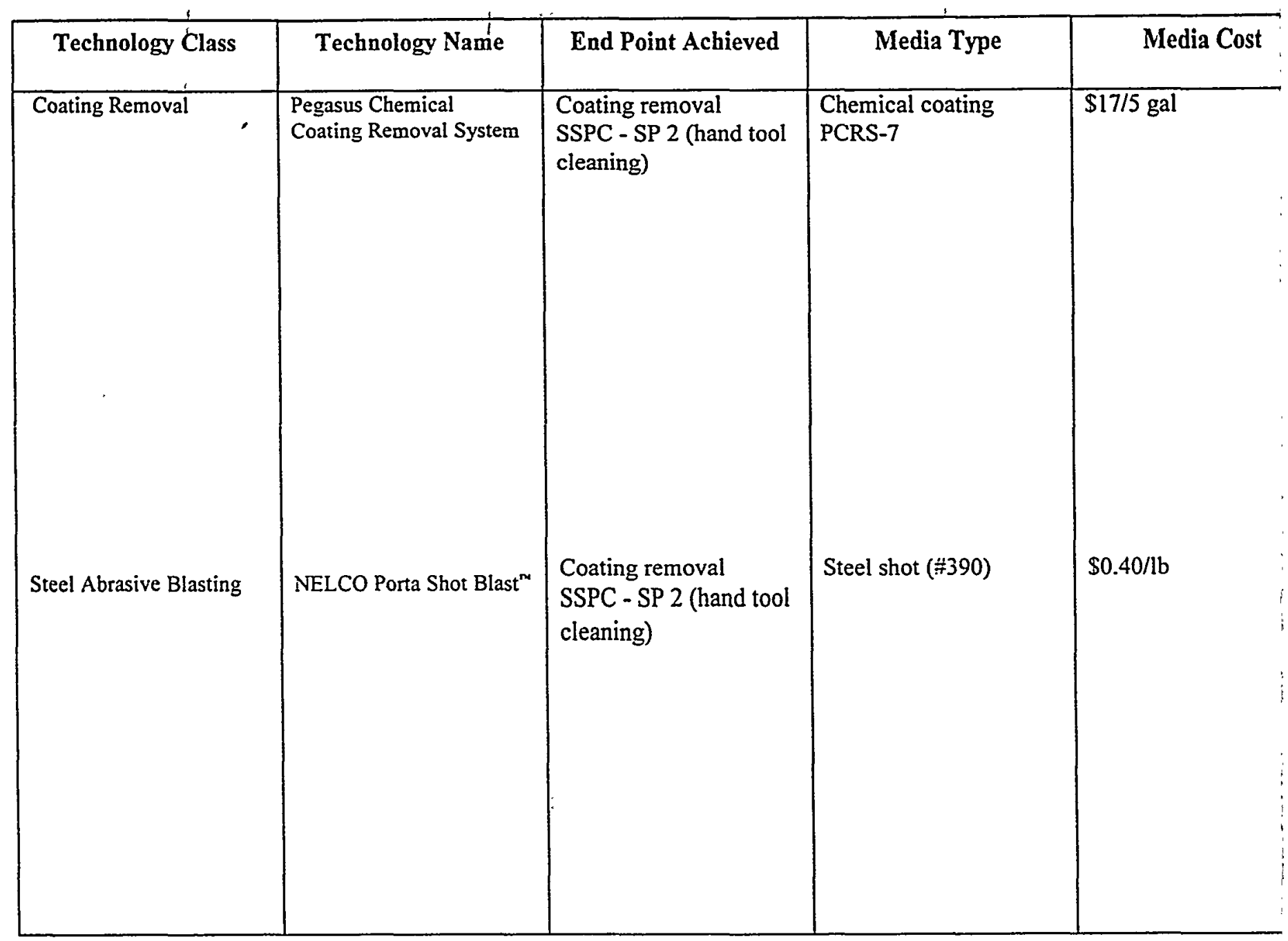


Utility/Me

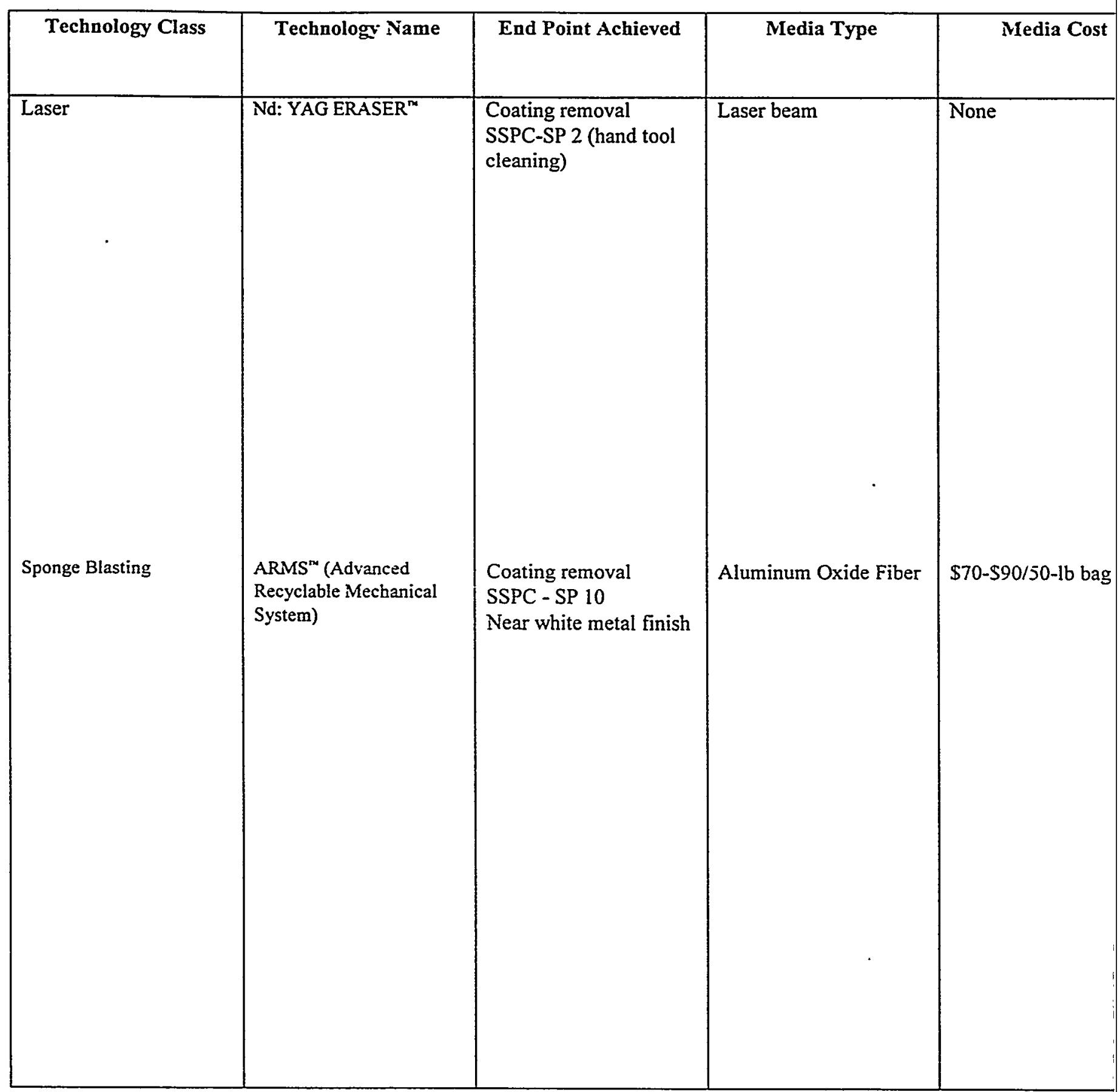


VENDOR INFORMATION 
Table D.1

Vendor Information

\begin{tabular}{|c|c|c|c|c|}
\hline Technology Name & $\begin{array}{l}\text { NELCO PORTA SHOT } \\
\text { BLAST }^{\text {m }} \text { (JHJ-2000) }\end{array}$ & PCRS-7 & $\begin{array}{l}\text { ADVANCED } \\
\text { RECYCLABLE } \\
\text { MECHANICAL } \\
\text { SYSTEMS }\end{array}$ & YAG ERASER ${ }^{\text {m }}$ \\
\hline Vendor Name & Pegasus International, Inc. & Pegasus International, Inc. & $\begin{array}{c}\text { Surface Technology } \\
\text { Systems }\end{array}$ & EXITECH Corporation \\
\hline Vendor Address & $\begin{array}{l}106 \text { Railroad Street } \\
\text { Schenley, PA } 15682\end{array}$ & $\begin{array}{l}106 \text { Railroad Street } \\
\text { Schenley, PA } 15682\end{array}$ & $\begin{array}{l}75 \text { East Market St. } \\
\text { Akron, } \mathrm{OH} 44308\end{array}$ & $\begin{array}{c}102 \text { East Broadway } \\
\text { Maryville, Tennessee } \\
37865\end{array}$ \\
\hline Phone Number & (412) 845-2838 & $(412) 845-2838$ & (330) 849-6695 & $(423) 983-9101$ \\
\hline Fax Number & $(412) 845-1794$ & $(412) 845-1794$ & (330) 374-0101 & (423) 983-9336 \\
\hline Services & $\begin{array}{c}\text { Equipment and service } \\
\text { provider }\end{array}$ & $\begin{array}{l}\text { Equipment and service } \\
\text { provider }\end{array}$ & $\begin{array}{c}\text { Equipment and service } \\
\text { provider }\end{array}$ & $\begin{array}{c}\text { Equipment and service } \\
\text { provider }\end{array}$ \\
\hline
\end{tabular}

